\title{
Character displacement within the breeding area questions reinforcement in Ficedula flycatchers
}

\author{
Vladimir G. Grinkov ${ }^{1 *}$, Igor V. Palko², Helmut Sternberg ${ }^{3}$ \\ ${ }^{1}$ Department of Biological Evolution, Faculty of Biology, Lomonosov Moscow State \\ University, Moscow, Russian Federation \\ ${ }^{2}$ Severtsov Institute of Ecology and Evolution, Russian Academy of Sciences, Moscow, \\ Russian Federation \\ ${ }^{3}$ OAG f. Populationsforschung Braunschweig, Braunschweig, Germany \\ *Correspondence to: grinkov@mail.bio.msu.ru
}

\section{Abstract}

At present, studies of reinforcement should be focused on demonstrating how often this process occurs in nature and how important it is for speciation. Here we study the character displacement within the breeding area in the Pied Flycatcher to check the validity of the reinforcement in Ficedula flycatchers. We used point-referenced spatial data and a random forest to find the most important explanatory factors of the character displacement, and to reconstruct the phenotypic structure of the populations. The environmental temperature, and not the distance to sympatry, were proven to better describe the geographic pattern of the mean breeding plumage colour of the Pied Flycatcher populations. We conclude that ecologically distinct adaptations drive the morphological differentiation of the Old World flycatchers, and not reinforcement.

Keywords: character displacement, reinforcement, phenotypic structure, random forest, Ficedula flycatchers, pied flycatcher, collared flycatcher

\section{Introduction}

Reinforcement (Dobzhansky 1937) is the process of enhancing reproductive isolation directly controlled by natural selection to cancel maladaptive hybridization between nascent species living together in the same territory (in sympatry). Often reinforcement is considered as one of the ways to complete the speciation process (Lewontin 1974; Servedio 2004). Scientific acceptance of the theory at the time of its appearance was very high, but in the eighties, it fell drastically (Noor 1999). To date, however, doubts about the existence of reinforcement have been resolved both by theoretical studies and by the identification of such cases in nature (Noor 1999; Servedio and Noor 2003; Butlin and Smadja 2018). Now researchers would change the focus of reinforcement studies to show how often this process occurs in nature and how important it is for speciation (Servedio 
and Noor 2003). Therefore, we are addressing to answer these questions by the case study of the character displacement (Brown and Wilson 1956) within the breeding area in the Pied Flycatcher (Ficedula hypoleuca).

After the publication of Sætre et al. (Saetre et al. 1997), relationships between the Pied Flycatcher and the Collared Flycatcher ( $F$. albicollis) had come to be considered one of the examples of reinforcement, although similar ideas were expressed several times before (Kral et al. 1988; Alatalo et al. 1990a; Lundberg and Alatalo 1992; Alatalo et al. 1994). The Pied Flycatcher breeding range is many times larger than the one of the Collared Flycatcher (Fig. 1). Most of the Pied Flycatcher breeding area does not overlap with the one of the Collared Flycatcher (allopatric populations), while most of the Collared Flycatcher breeding range coincides with the breeding area of the Pied Flycatcher (Fig. 1). Where the ranges of these two species of flycatchers overlap (areas of sympatry, for example, in Central and Eastern Europe), males with a brown colouration of breeding plumage (brown morph) predominate in populations of the Pied Flycatcher. This colouration is very similar to that of females of this species. In the allopatric area (for example, in Fennoscandia), contrastingly coloured males with a black and white colour of the breeding plumage (black morph) predominate in populations of the Pied Flycatcher (Fig. $1 \mathrm{~A}$ and $\mathrm{B}$ ). Such a biographical pattern of the morph ratio in the Pied Flycatcher is fundamental to the assumption that the character displacement within the breeding area of the species is the result of reinforcement (Saetre et al. 1997). However, the coupling of a high proportion of brown males with areas of sympatry in the Pied Flycatcher is revealed only for European populations, without analysing the phenotypic structure of those populations that breed in the most eastern European and the Asian part of the species breeding range (for example, in the European part of Russia to the Ural Mountains and further to Western Siberia, Fig. 1C).

In parallel with the publication of Sætre et al. (Saetre et al. 1997), it was nevertheless noted that the authors' conclusions indeed are based on limited material. "Both the phylogeny and the data on mate choice are based on limited sampling. The case for reinforcement will be more secure when the generality of the preferences has been established, and when a more complete picture of the biogeographic history of the flycatchers is available", wrote R. K. Butlin and T. Tregenza (Butlin and Tregenza 1997). However, these comments were not considered in the following studies (Noor 1999; Servedio and Noor 2003).

In this paper, we decided to follow the opinion of R. K. Butlin and T. Tregenza and conduct a biogeographic study of flycatchers on the largest material that we can obtain for analysis today. Specifically, we checked whether there is a relationship between the 
prevailing breeding plumage colour in males and the remoteness of the Pied Flycatcher population from the breeding area of the Collared Flycatcher. To do this, we collected all the data known to us about the phenotypic structure of all populations of the Pied Flycatcher currently studied. We managed to find information for 41 populations. In addition, we analysed zoological collections from 11 museums. This allowed us to further evaluate the phenotypic structure of another 38 metapopulations of the Pied Flycatcher. To check whether the distance from the nesting area of the Collared Flycatcher may have an impact on the phenotypic structure of the Pied Flycatcher, we used a random forest as spatial predictions framework (Hengl et al. 2018). The extensive data sampling and spatial analyses usage largely distinguish our work from similar attempts, in which limited sampling and the linear regression models were used for these purposes (Laaksonen et al. 2015).

\section{Material and Methods}

\section{Basic methodological approach}

We used point-referenced spatial data and a random forest for spatial predictions framework (RFsp) (Hengl et al. 2018) to find (1) the most important predictor variables highly related to the mean colour score of the males' breeding plumage of the Pied Flycatcher populations (response variable), and (2) a good parsimonious prediction model of the response variable for any point of the breeding range of the Pied Flycatcher. The RFsp was chosen because it can obtain equally accurate and unbiased predictions as other methods of spatial analysis (generalized linear model, different versions of kriging, geographically weighted regression) (Čeh et al. 2018; Hengl et al. 2018). The RFsp is thought to be advantageous over the other spatial analyses for the purpose of this research, as the former needs no rigid statistical assumptions about the distribution and stationarity of the target variable, it is more flexible towards incorporating, combining and extending covariates of different types, and information overlap (multicollinearity) and over-parameterization is not a problem for RFsp (Hengl et al. 2018). The distances from "observation points" to the border of the breeding area of the Collared Flycatcher and geographical coordinates (latitude and longitude) of "observation points" are used as explanatory variables, thus incorporating geographical proximity and geographical connection effects into the prediction process (Hengl et al. 2018). The "observation points" are $F$. hypolueca population "centres" for which the mean breeding plumage colour score was obtained (see below). We used the average daily maximum temperature and its variability (standard deviation) as general climatic characteristics of the population habitat. We put thermal characteristics into the model as alternative explanatory variables, thus contrasting them with the distance to the sympatry area during the prediction process. We 
used thermal characteristics in the analysis because it was shown that there is a low air temperature depression of the advertising behaviour of brown males in the Pied Flycatcher (Ilyina and Ivankina 2001; Kerimov et al. 2014), and this can lead to an increase in the proportion of black males in the reproductive part of the Pied Flycatcher population in cold spring years (Kerimov et al. 2014). Additionally, the basal metabolic rate (the amount of energy per unit time that an individual must spend to keep the body functioning at rest) and fledgling production of the males' morphs in the $F$. hypoleuca flycatcher were shown to be dependent on the ambient temperature (Sirkia et al. 2010; Kerimov et al. 2014).

\section{Data collection and preparation}

Step I. As a source of temperature data, we used The National Centers for Environmental Prediction (NCEP) / National Center for Atmospheric Research (NCAR) Reanalysis data set R-1, and NCEP / Department of Energy (DOE) Reanalysis II data set R-2 (Kalnay et al. 1996; Kanamitsu et al. 2002). The NCEP/NCAR R-1 and NCEP/DOE R-2 are high-quality, well-documented, freely available state-of-the-art gridded reanalysis data sets with global coverage of many relevant atmospheric variables spanning 1957 to present and 1979 to present, respectively (Kemp et al. 2012). Data for many variables are available at 17 pressure levels ranging from 1000 to $10 \mathrm{mb}$. Other variables describe conditions either at or near the surface. These data have a spatial resolution of $2.5 \times 2.5$ degrees and a temporal resolution of $6 \mathrm{~h}(00,06,12,18 \mathrm{~h}$ UTC). We used the RNCEP package (version 1.0.8) of functions (Kemp et al. 2012) in the open-source $R$ language to access required temperature data. First, using the NCEP.gather function from the RNCEP package, we loaded surface temperature data (variable air.sig995 in data set) from April to May for each year in the interval spanning 1980 to 2015 for an area between 35- and 72-degrees north latitude and between -10- and 93-degrees longitude thus covering the breeding areas of the two species of flycatchers. Then using the NCEP.restrict function, we cut the interval from April 1 to April 14 and from May 16 to May 31, leaving the period from April 15 to May 15 for all loaded years. Finally, using the NCEP.aggregate function, we calculated the mean and standard deviation (SD) of daily maximum temperature for all loaded years, obtaining a point pattern of mean temperatures and SDs for the entire loaded area with a spatial resolution of $2.5 \times 2.5$ degrees of latitude $x$ longitude. Similarly, we calculated the SD of the maximum daily temperature for May 1 for all years (the rendered thermal data map, see Fig. 2.). The latter assessment of variability mostly characterizes the repeatability or the predictability of temperature between years, and the former SD includes both inter-annual and intra-annual (inter-seasonal) variability, that is, a change in temperature from April 15 to May 15. Inter-seasonal temperature changes will be significantly higher for the continental climate than for the temperate climate. The selected interval spanning 1980 to 
2015 seems to be sufficient both for obtaining an unbiased estimate of average temperatures and for a satisfactory assessment of its variability. The selected date interval, which lasts from April 15 to May 15, covers the period of birds' arrival from African wintering grounds, pairing and the beginning of reproduction in most of the populations of considered species of flycatchers. Since the key principle of geography is that "everything is related to everything else, but near things are more related than distant things" (Miller 2004), the climatic characteristics of earlier or later periods or months (March or June, for example) will be highly correlated with the chosen one. Temporal and spatial autocorrelations of temperature data are well-founded and documented facts in modern science, for example, see (Di Cecco and Gouhier 2018). Our goal was not to understand the temperature of which the nesting period determines the phenotypic composition of the population to a greater degree (causation task); this is a task for other studies. We evaluated which variable better predicts the values of the response variable (correlation task). And in this sense, temporal and spatial autocorrelations of the temperatures are not a nuisance for us, but a feature that improves our approach, since it allows a rather arbitrary choice of the period for calculating thermal estimates.

Step II. We were looking for any articles studying the Pied Flycatcher that mentioned the phenotypic structure of this species. Seven variants (types or morphs) were initially identified in the variability range of the male breeding plumage colour in the Pied Flycatcher (Drost 1936). The value 1 of this scale was assigned to the bright coloured black and white males, and the value 7 assigned to the brown coloured males. Accordingly, it is easy to calculate the average colour score of the population, which will describe well the proportion of males of different morphs. The closer the average colour score is to 1 ,

165 the greater number of black males there are, the blacker is the population as a whole and vice versa; the closer to 7 , the greater number of brown males in the population, the browner is the population. In most of the publications, the mean colour score is given, therefore in our work we also used this indicator as the main descriptor of the phenotypic structure. We were able to find information about the phenotypic structure of the Pied Flycatcher for 41 populations (or metapopulations) (Table S1). For each, we found the nearest well-recognized geographical point. Usually it was nearest settlement to which the studied bird population was attributed by the author(s). We found the geographic coordinates in the QGIS program for this point. This geographic point was the "observation point" for those populations whose data on the phenotypic structure were obtained from publications. We used data from the same author (or the same group of authors) for one territory from only one most recent publication. If for the same territory (or a close region) we found data from different authors, then we used all such data in the calculations. 
Step III. The Pied Flycatcher studies in the western part of the breeding range were carried out much more often than in the eastern part resulting in a shifted distribution of observation points (Table S1). To compensate for data bias, we examined the collections of the following museums: [1] Siberian Zoological Museum of the Institute of Systematics and Ecology of the Siberian Branch of the Russian Academy of Sciences (Novosibirsk), [2] Collection of the Department of Biogeography of the Faculty of Geography of the M. V. Lomonosov Moscow State University (Moscow), [3] State Museum of Nature of the Kharkiv National V.N. Karazin University (Kharkiv), [4] Zoological Museum of Kyiv National Taras Shevchenko University (Kiev), [5] Zoological Museum of Lviv National I. Frank University (Lviv), [6] Zoological Museum of the Belarusian State University (Minsk), [7] Zoological Museum of the M. V. Lomonosov Moscow State University (Moscow), [8] Zoological Museum of the National Academy of Sciences of Ukraine (Kiev), [9] Zoological Museum of the Zoological Institute of the Russian Academy of Sciences (St. Petersburg), [10] Kirov City Zoological Museum (Kirov), [11] Kaunas Zoological T. Ivanauskas Museum (Kaunas), [12] Museum of Natural History of Tartu University (Tartu).

We examined the bird skin collection and determined the colour type of bird skins in museums [1] - [9]. Data on the colour type of 17 males were kindly provided by $\mathrm{V}$. N. Sotnikov from [10]. We received digital photographs of 12 and 11 bird skins from [11] and [12], respectively, for subsequent colour typing. In total, we examined 471 birds' skins, of which 39 skins were excluded because some of them were clearly taken from migratory birds (autumn migration), and for some of them we could not accurately determine the location. Finally, we got colour types for 432 bird skins from museums [2] - [12] (no skin from museum [1] was included in the final data set; see Data S1). For each skin, the geographic coordinate was determined in the QGIS, based on the description of the place where the birds were caught written on the label.

Since the spatial resolution of temperature data was $2.5 \times 2.5$ degrees of a geographic coordinate, we used polygons of that size to form "populations" (small area populations) (Fig. S4). The minimum sample for a population was 5 individuals, because this number is enough to calculate the mean deviating by less than 1 point of the colour score (a prespecified error bound) with a probability of 0.95 from the population total mean in a sample of 366 individuals with a standard deviation 1.13 (the population total mean sample size and the standard deviation were estimated in step II). If fewer individuals fell into some 2.5

$210 \times 2.5$ degrees polygon, we included such individuals in the nearest polygons defined by the QGIS. Such individuals should not be located from the polygons in which they were included at a distance greater than 1.25 degrees (Fig. S4). After this procedure, there were still individuals that did not form populations or were not included in a population. In such 
remaining cases, we gradually increased the size of the buffer from the geographical position of the individual, while the areas thus obtained began to overlap. If overlapping areas included 5 or more individuals, then we also considered them as the population for which the mean colour score was calculated (large area populations) (Fig. S4). We were unable to include 14 individuals in any of the populations using any of the above methods (Fig. S4). The "observation point" for populations formed by the skins from museum collections was calculated as the mean coordinate of all population components in QGIS (i.e. the centre of mass, and not the centroid which is the geometric centre of the population) (Fig. S4). We thus obtained 39 populations or observation points (Table S2).

As mentioned, not only breeding, but also migratory birds can get into museum collections. Also, the skin of birds can be collected purposefully of the same type or colour. It is relatively easy to separate autumn migrants by the bird life calendar and the plumage colouring (before the autumn migration, birds moult completely, and the colour of the post breeding plumage is quite different from the colour of the breeding one). However, in our opinion, it is impossible to separate spring migrants from local breeders. Thus, this problem was ignored by us, because we were unable to find criteria and procedures for cleaning the sample that would not lead to significant data loss. We found signs of directional collection of black males in only one case (the small standard deviation, a difference in the mean breeding plumage score from neighbouring populations) (Table S2). For one area in the sample of 6 individuals, there were five males with a colour score 2 and one male with a colour score 3 . Such a ratio of morphs is almost impossible to obtain with a random selection method even in dark populations. This observation point was excluded from the analysis (Table S2).

Step IV. For two species of $F$. hypoleuca and F. albicollis flycatchers, we downloaded the distribution data (digitized georeferenced maps in geodatabase file format for use in GIS mapping software compiled by BirdLife International and Handbook of the Birds of the World) from BirdLife International (2018) IUCN Red List for birds, http://www.birdlife.org (downloaded from the site on 09.09.2018 using QGIS). We revealed that the bird findings from the Kola Peninsula, and from the northernmost and easternmost parts of the $F$. hypoleuca breeding area in Western Siberia, do not fall into the BirdLife International reproductive range of $F$. hypoleuca. To adjust the range of $F$. hypoleuca, we georeferenced

245 in QGIS the species breeding area from the publication of Sirkia et al. (Sirkia et al. 2015). The final breeding range of $F$. hypoleuca basically contained the BirdLife International data, but the north-western borders were extended to the north and east to the coast of the Kola Peninsula, to the north of Western Siberia coinciding with the border from Sirkia et al. 
(Sirkia et al. 2015) for this region, and to the very east of Western Siberia thus including data from museum collections for the area.

We did not include the Spanish (Iberian) and north-western African Atlas Flycatcher in the range of $F$. hypoleuca (Fig. 1). The birds of these territories are well isolated from other European $F$. hypoleuca populations (they can occur in one territory during a migration only), and they are phenotypically closer to each other (Corso et al. 2015; Potti et al. 2016). The Iberian form seems to be intermediate between the African form and $F$. hypoleuca in morphology (Sangster et al. 2004). It is recommended that the Atlas Flycatcher $F$. speculigera should be separated from the Pied Flycatcher $F$. hypoleuca as a species, and the Iberian form should be considered as subspecies $F$. hypoleuca iberiae of $F$. hypoleuca (Sangster et al. 2004). Sometimes, Iberian birds are also distinguished as a separate species (Potti et al. 2016). In both F. speculigera and F. h. iberiae, the colour of the breeding plumage in males is mainly black-and-white, and its variability is much less than among birds from the rest of Europe (Corso et al. 2015).

We also corrected the north-eastern boundary of the $F$. albicollis breeding range (Moscow is not included in the nesting range of this species), using Vabishchevich and Formozov (Vabishchevich and Formozov 2010) georeferenced distribution data. Southern Sweden, the islands of Öland, Gotland and Saaremaa were also excluded from the final $F$. albicollis breeding range due to the recent expansion of the species over the Baltic Sea thus following Laaksonen et al. (Laaksonen et al. 2015) (Fig. 1).

Step V. All data obtained in the previous steps were entered QGIS for their final assembly. For each $F$. hypoleuca observation point, the distance in kilometres to the boundary of the $F$. albicollis range was calculated (Fig. 1). If the observation point fell inside the $F$. albicollis range, the distance got negative values. Binding of the $F$. hypoleuca observation point to the thermal characteristics of the territory was carried out using the method of the nearest neighbour (the nearest point-referenced values of the thermal characteristics of the territory were chosen), as well as by Inverse Distance Weighted (IDW) interpolation using the 4 nearest points. We used the GRASS 7 v.surf.idw algorithm for surface interpolation from point-referenced data by the IDW interpolation for which region the cellsize was set to 2.5 (according with the spatial resolution of the temperature data), the power parameter was set to 3 , and the number of interpolation points was set to 4 .

280 Then we used the point sampling tool to assign the interpolated value to the population observation point.

Thus, our initial model consisted of one response variable (the mean breeding plumage colour of $F$. hypoleuca males in the population) and 9 predictors: $Y$ - latitude, $X$ longitude, cf.dist - distance to the border of the $F$. albicollis range, $m t$ - mean maximum 
daily temperature of the nearest temperature referenced point, $m t$.idw - IDW interpolated mean maximum daily temperature, $s d$ - standard deviation of the maximum daily temperature from April 15 to May 15 spanning 1980 to 2015 of the nearest temperature referenced point, sd.idw - IDW interpolated standard deviation of the maximum daily temperature from April 15 to May 15 spanning 1980 to 2015, sd.1d - standard deviation of the maximum day temperature for May 1 spanning 1980 to 2015 of the nearest temperature referenced point, and finally sd.1d.idw - IDW interpolated standard deviation of the maximum day temperature for May 1 spanning 1980 to 2015.

\section{$\underline{\text { Spatial data analysis }}$}

We used the open-source R software environment for statistical computing and graphics (version 3.5.0) under an integrated development environment for R - RStudio (RStudio Desktop version 1.1.447) to analyse data assembled on step V. For regression tasks we used the ranger package (version 0.10.1) as an implementation of the random forests (Wright and Ziegler 2017). To obtain the most accurate predictions, the random forest parameters need to be optimised (Probst et al. 2018). To configure the parameters

300 of the random forest, we used the tuneRanger (version 0.3) package (Probst et al. 2018) which allows model-based optimization for tuning strategy and the three parameters min.node.size, sample.fraction and mtry tuning at once. Out-of-bag predictions were used for evaluation. To evaluate the best num.trees parameter, we used the caret (version 6.080) package. We used a trainControl function from the package to set the resampling method to 10 -fold cross-validation procedure. Validation was done by calculating the root mean squared error (RMSE). Thus, the initial model, which included all 9 predictors, was calculated with the following parameters of the random forest: min.node. size $=8$, sample. fraction=0.79, mtry=2, num.trees $=250$, splitrule = "variance", importance ="impurity", num.threads $=4$, verbose=FALSE, respect. unordered.factors $=$ TRUE, replace=FALSE, keep.inbag=TRUE. We obtained the coefficient of determination for the whole model $\left(\mathrm{R}^{2}\right)$ equal to 0.73 (out-of-bag predictions), and the mean squared error (MSE) equal to 0.24 (out-of-bag prediction error). To build the most parsimonious prediction model of the response variable, i.e. to reduce the number of predictors with minimal impact on the response variable, we conducted a nested cross-validation procedure using the caret package. We estimated the 10-fold cross-validated prediction performance of models with a sequentially reduced number of predictors ranked by variable importance (the variables with the lowest variable importance values was sequentially excluded from the models) in 100 repetitions (Fig. 3). In our case the variable importance was measured as the variance of the responses (Fig. $3 \mathrm{C}$ ). Validation of the models was done by calculating the RMSE (Fig. 3A). The cross-validation procedure reduced 4 of 9 predictors (including the distance 
to the $F$. albicollis breeding area), and the final model performance increased slightly, but statistically significantly (Fig. 3A, B). Thus, the final model included only 5 predictors listed below: $Y, X, m t, s d, s d .1 d$. After excluding 4 predictors from the model, we again conducted the above procedure for the parameter's optimization of the random forest. The final model was calculated with the following parameters: $\min$.node. size $=11$, sample. fraction $=0.787$, mtry $=2$, num.trees $=250$, splitrule $=$ "variance", importance="impurity", num.threads $=4$, verbose $=F A L S E$, respect.unordered. factors $=T R U E$, replace $=F A L S E$, keep.inbag $=T R U E$. The $R^{2}$ for the whole final model is 0.75 , and the MSE is 0.23 . To predict the mean breeding plumage colour score of males in the $F$. hypoleuca within the entire breeding range (to calculate out of sample data), we used the predict.ranger function in the ranger package with the final random forest model. The values of all 5 predictors obtained in step 1 for the area between 35- and 72-degrees north latitude and between -10- and 93-degrees longitude were used. We calculated the standard error of the predictions using the infinitesimal jackknife for bagging methodology (Wager et al. 2014) as it implemented in the ranger package (Fig. 4, Fig. S2).

Data visualization

To visualize the results of spatial analysis, we transformed point-referenced data into raster surface data in the QGIS. For this, we used the GRASS 7 v.surf.idw algorithm for surface interpolation from point-referenced data by the IDW interpolation (region cellsize was set to 2.5 , power parameter was set to 3 , and number of interpolation points was set to 4). To improve the spatial resolution of raster data and to improve the visualization effect, we used the SAGA Resampling algorithm with upscaling and downscaling IDW interpolation. We changed the cellsize parameter to obtain the most acceptable visualization effect (usually, the parameter value was equal or less than 0.1 ). To draw all the other graphs, we used the ggplot2 (Wickham 2016) (version 3.0.0) package in R. Final processing of the vector-based drawings was carried out in Inkscape ${ }^{\mathrm{Tm}}$ : Open Source Scalable Vector Graphics Editor (version 0.92.3), and the raster-based drawings was done in GNU Image Manipulation Program (GIMP) (version 2.10.4).

Modelling the influence of the $F$. albicollis flycatcher on the population phenotypic structure of the $F$. hypoleuca flycatcher

In the QGIS program, we modelled a hypothetical phenotypic structure of the $F$. hypoleuca populations, as if only one single factor was acting on the distance from the $F$. albicollis breeding range. This simulation was carried out only for visualization and was not used in statistical treatment. First, we transformed the $F$. albicollis range into a raster using the SAGA rasterize data/nodata algorithm, and then modelled the distance effect from the 
borders using the r.grow.distance algorithm with the cell size parameter set to 1 . The final visualization was done using the above data visualization methods (Fig. S3).

\section{$\underline{\text { H. Löhrl data processing }}$}

The figure 2 given on page 271 of the $\mathrm{H}$. Löhrl publication in Bonner Zoologische Beiträge (Löhrl 1965) was georeferenced in QGIS. We have downloaded freely accessible The Global Multi-resolution Terrain Elevation Data 2010 (GMTED2010) from the EarthExplorer site (https://earthexplorer.usgs.gov/) for the south-west of Germany and adjacent territories. We used the point sampling tool in QGIS to assign the terrain elevation values to the $\mathrm{H}$. Löhrl observation points for further processing in R (Fig. 5).

\section{Results}

A simple graphical analysis of the relationship between the mean colour score and the predictors showed that there are obvious non-linear dependencies in the data structure, including the dependence of the response variable on the distance from the observation point to the sympatry area (Fig. S1). In this regard, the use of linear models cannot be considered as a quite adequate method of analysing such data (Laaksonen et al. 2015).

The thermal characteristics of the area covering the ranges of the flycatcher species demonstrate a strong, but quite expected pattern of variability. Within the Pied Flycatcher distribution area, there is a pronounced south-north gradient of average daily maximum temperatures (Fig. 2). It is particularly pronounced between Central and Eastern Europe on the one hand and Fennoscandia on the other. The variability and predictability of thermal characteristics has a more complex geographic pattern, although in general there is a tendency to increase unpredictability eastward (an increase in the climate continentality as one moves deeper into Eurasia) (Fig. 2).

We used a spatially explicit approach to achieve two main objectives. Firstly, for the purposes of interpretation, we found the most important variables highly related to the population mean colour score of the males' breeding plumage of the Pied Flycatcher (response variable). Secondly, we found the smallest number of variables enough for a good parsimonious prediction of the mean colour score of the males' breeding plumage for any point of the breeding range of the Pied Flycatcher.

The random forest regression has shown that the distance to the breeding area of the Collared Flycatcher is of minimal importance for predicting the phenotypic structure of the Pied Flycatcher populations (Fig. 3). The average daily maximum temperature during the breeding season and its variability are associated with the predominant male colour morph in each population of the species (Fig. 3). Latitude and longitude also affect the phenotypic structure of the Pied Flycatcher populations (Fig. 3). This may indicate that we 
did not include any other important variables associated with the geographical location of the population in the study.

Model predictions show that the predominance of black morphs in males is observed in the Pied Flycatcher populations nesting in areas with a predictably colder environment (Fennoscandia and the British Isles) (Fig. 4, Fig. S2). Brown-coloured males predominate in populations nesting in a relatively warm and/or very unstable climate. Populations with a predominance of brown morphs form the entire southern region of the breeding range of the Pied Flycatcher, including the most Eastern European part and the Western Siberian part. Moreover, the populations in which the average values of the colour score reach maximum values (more brown morphs in the population) are outside the breeding range of the Collared Flycatcher - these are central and northern Germany, and the Netherlands (Fig. 4). In sympatry, the phenotypic structure of the Pied Flycatcher populations also changes (Fig. 4), and these changes have a much more complex spatial pattern compared to what one would assume if the mere presence/absence of another species would influence the phenotypic structure of sympatric populations (Fig. S3).

\section{Discussion}

The study of the mechanisms of speciation in the Old World flycatchers of the genus Ficedula, unfortunately, recalls the very case when the cart was putted before the horse. Acceptance of reinforcement as the main factor of speciation in the Ficedula flycatchers and as the mechanism of maintaining intraspecific variability in one of them (Saetre and Saether 2010) occurred even though the biogeographic pattern of phenotypic structure was not revealed for the whole breeding area of the interacted species, and the generality of the female preferences for male breeding plumage was not established.

Surprisingly, data on the mainly brown coloration of the males' breeding plumage of the Pied Flycatcher in Western Siberia were available in the scientific literature (Johansen 1954). Apparently, this information was not widely known. This fact alone would be enough to cast doubt on the generality of the coupling between the character displacement and the areas of sympatry. Now we can say with high certainty that no convincing evidence of the coincidence of the character displacement and the sympatry areas of the flycatchers exist (Fig. 4). Our studies persuasively show that the geographic pattern of variability of the mean colour score of males' breeding plumage in the Pied Flycatcher is much more complicated and cannot be caused solely by interspecific interactions (Fig. 1, Fig. 4 and Fig. S3). For example, the shift of male breeding plumage colouration occurs in the sympatry, but also in the allopatry in most eastern parts of the breeding range of the Pied Flycatcher up to the eastern distribution boundaries in Western Siberia, that is, the most remote populations from the areas of sympatry (Fig. 1 and Fig. 4). 
It is crucially important that if reinforcement is inferred from displacement in a secondary male sexual character, the displacement must be detectable by females; and females should use these characters for a mate choice (Howard 1993; Noor 1999). In addition to the publication of Sætre et al. (Saetre et al. 1997), some other studies reveal that a female preferably chooses a black male in allopatric populations of the Pied Flycatcher (Roskaft and Jarvi 1983; Saetre et al. 1994; Dale and Slagsvold 1996). However, there are also several studies done by independent researchers about different allopatric populations in which no clear benefits for black morphs in mate choice were found (Alatalo et al. 1986; Alatalo et al. 1990b; Potti and Montalvo 1991; Lehtonen et al. 2009; Sirkia and Laaksonen 2009). This indicates that the generality of the female preferences for male breeding plumage in the Pied Flycatcher also cannot be considered a fully proven phenomenon.

We think that if the female perceives the male breeding plumage colour as a cue to select a mate, this male trait is not the main one for mate choice or not used at all. For example, it was recently shown that the intensity of the advertising behaviour of free-living males of the Pied Flycatcher is modified by ambient air temperatures in the Moscow Region population (Russia, European part). Black males can maintain a high intensity of advertising behaviour at both low and high temperatures. However, brown males are able to attract females effectively only at higher air temperatures, and at low temperatures reduce dramatically the intensity of advertising behaviour (Ilyina and Ivankina 2001; Kerimov et al. 2014). Quite similar results were obtained in the experiments in the Tomsk population (Russia, Western Siberia) of the Pied Flycatcher. It was shown that females choose black males at low ambient temperatures merely because they are more active

450 (Kerimov et al. 2014). Moreover, it was possible to demonstrate that this mechanism influences the morph ratio in the reproductive part of the population - in years with a cold spring, more black males enter the reproductive part of the Tomsk population, apparently due to the temperature-related depression of the brown males' advertising behaviour (Kerimov et al. 2014). In the literature, there is also evidence that the ambient temperature can affect the reproductive success and the energetics of the morphs. The reproductive output of black males was shown to be the highest when it was cold during egg-laying but warm during the nestling period, whereas the fledgling production of brown males was highest when it was continuously warm (Sirkia et al. 2010). Brown males increase a basal metabolic rate (BMR; the amount of energy per unit time that an individual must spend to keep the body functioning at rest) under the influence of low ambient temperatures, and black males, on the contrary, retain the same level of BMR in a very wide range of daily temperatures (Kerimov et al. 2014). It is likely that the opposed results of earlier studies of female morph preferences could be obtained because the temperature dependence of the 
males' energetics and behaviour was not considered. To date, data from Sætre et al.

(Saetre et al. 1997) remain the only "strong" evidence of reinforcement (Saetre and Saether 2010) (all others are not an exclusive prerogative of reinforcement) (Noor 1999; Butlin and Smadja 2018). Therefore, the replication of the experiments of Sætre et al. (Saetre et al. 1997) to check the female preferences is necessary on a more extensive material, considering the new information about the dependence of the males' advertising behaviour on ambient temperatures.

The coupling of males' breeding plumage colour variability with weather characteristics in the Pied Flycatcher was noted in one of the first studies devoted to this issue. Löhrl (Löhrl 1965) described a very interesting picture of the spatial segregation of male morphs of the Pied Flycatcher and the Collared Flycatcher. He showed that in southwest Germany brown and black males of the Pied Flycatcher are separated from each other spatially, as well as from the Collared Flycatcher (Fig. 5). Brown males occupied the forests of the lowest lands, the Collared Flycatcher occupied the forests at medium height above sea level, and the black males nested in the highest mountain forests. Such a clear spatial segregation between two species and morphs cannot be explained by a simple

480 interference competition over nest cavities, where the collared flycatcher is a winner (Saetre and Saether 2010). This habitat segregation on such a spatial scale can only be the result of an active habitat choice. Indeed, there is experimental evidence for speciesspecific habitat preferences in two flycatcher species in their hybrid zone (Adamik and Bures 2007).

All these data can be regarded as evidence considering that the evolution of the plumage colour in the Pied Flycatcher is not driven by reinforcement but is the result of the adaptation of black males to the conditions of higher mountains forests, and brown ones to the conditions of lower-altitude forests. Then the distribution of brown and black populations of the Pied Flycatcher along the modern breeding area is a projection of adaptations to different ecological subniches that the species have developed in refugia during the last glaciation ( $F$. albicollis in Italy, and F. hypolueca on the Iberian Peninsula) and their subsequent evolution (Saetre and Saether 2010).

It is very likely that the initial stages of the $F$. hypolueca species formation took place in the relatively higher-altitude conditions of the north of the Iberian Peninsula refuge 495 during Quaternary ice ages (for the European paleoenvironments and maximum extent of ice, for example, see (Tzedakis et al. 2013). Further, as the glaciation receded, the $F$. hypolueca began to expand earlier along its current range, since there are no physical obstacles in this refugium like the Alps in the north of the Apennine Peninsula. Probably, as a result of this expansion, an adaptation to breeding in lower-altitude forests evolved, 
500 marked by the brown colour of the male breeding plumage. The expansion of the $F$. albicollis from its Italian refuge could be limited to the Alps for some time. As a result, when $F$. albicollis began to spread over its existing range, it encountered the brown $F$. hypolueca populations that had spread a little bit earlier. In contact zones the species effectively diverged to different ecological niches, although the $F$. albicollis remained a more stenobiont species (Qvarnstrom et al. 2010). At present, the species are so well segregated ecologically that there may be no competition for microhabitats and nesting sites between them (Walankiewicz et al. 1997; Adamik and Bures 2007; Czeszczewik et al. 2012). Therefore, it seems very likely that the black $F$. hypolueca populations have never shared the same habitats with the $F$. albicollis throughout the entire evolutionary history of these species! Thus, at present the British Isles and Fennoscandia are inhabited by black males preadapted to higher-altitude forests (ancestral state), and the southern and eastern parts of the Pied Flycatcher range are inhabited by brown males adapted to lower-altitude forests (newly evolved state). Thus, there is a clear ecological background for the evolution of the breeding plumage colour in the Pied Flycatcher males as an alternative for reinforcement including ecological adaptation, niche differentiation, and ecological character displacement.

In theoretical studies it was noted that in order to attribute mate choice patterns to reinforcement it was necessary that the character displacement must not have occurred for other, especially ecological reasons (Howard 1993; Noor 1999). This requirement is one where many studies have failed (Howard 1993; Noor 1999), and the reinforcement in Ficedula flycatchers seems to have to fill their numbers.

\section{Acknowledgments}

We are very grateful to our colleagues from museums and universities for their support in collecting data: A.M. Peklo, L.N. Prokopchuk, A.A. Atemasov, V.F. Chernikov, Y.A. Redkin, P.S. Tomkovich, M.V. Kalyakin, L.G. Emelyanova, A.D. Pisanenko, E.A. Srebrodolskaya, A.V. Bokotey, V.M. Loskot, V.N. Sotnikov, A.I. Milutin, S. Rumbutis, A.P. Vabishchevich. We are thankful to N.A. Formozov for consultations. We are grateful to K. Henne for improving the English language of an earlier version of the manuscript.

Funding: This work was supported by the Russian Fund of Basic Research RFBR (project 18-04-00536-a) and the State Assignment Ch. 2 CITIS AAAA-A16-116021660031-5.

Author contributions: The conceptualization, data curation, funding acquisition, investigation, methodology, resources, validation, visualization, review, and editing were equally distributed among co-authors. Besides the listed, V.G. Grinkov was responsible for supervision, project administration, formal statistical analysis, and writing the original draft. Competing interests: The authors declare no competing interests. 
Data and materials availability: All data and software are available in the main text, the supplementary materials, and on the internet sites for purposes of reproducing the results or extending the analysis.

\section{Software and data sources:}

540 Quantum GIS Development Team. 2013. QGIS Geographic Information System. Open Source Geospatial Foundation Project. https://qgis.org

R Core Team. 2018. R: A language and environment for statistical computing. R Foundation for Statistical Computing, Vienna, Austria. https://www.r-project.org/

RStudio Team. 2016. RStudio: Integrated Development for R. RStudio, Inc. Boston, MA. http://www.rstudio.com/.

Environmental Prediction (NCEP)/National Center for Atmospheric Research (NCAR) Reanalysis data set R-1. URL http://www.cpc.ncep.noaa.gov/products/wesley/reanalysis.html Environmental Prediction (NCEP)/Department of Energy (DOE) Reanalysis II data set R-2. URL http://www.cpc.ncep.noaa.gov/products/wesley/reanalysis2/index.html

Global Multi-resolution Terrain Elevation Data 2010 (GMTED2010). the EarthExplorer. URL https://earthexplorer.usgs.gov/

Species distribution data compiled by BirdLife International and Handbook of the Birds of the World from BirdLife International (2018) IUCN Red List for birds. URL

\section{Literature Cited}

Adamik, P. and S. Bures. 2007. Experimental evidence for species-specific habitat preferences in two flycatcher species in their hybrid zone. Naturwissenschaften 94:859-863.

Alatalo, R. V., D. Eriksson, L. Gustafsson, and A. Lundberg. 1990a. Hybridization between Pied and Collared Flycatchers - Sexual selection and speciation theory. J Evolution Biol 3:375-389.

Alatalo, R. V., L. Gustafsson, and A. Lundberg. 1994. Male coloration and species recognition in sympatric flycatchers. P R Soc B 256:113-118.

Alatalo, R. V., A. Lundberg, and C. Glynn. 1986. Female pied flycatchers choose territory quality and not male characteristics. Nature 323:152-153.

Alatalo, R. V., A. Lundberg, and J. Sundberg. 1990b. Can female preference explain sexual dichromatism in the pied flycatcher, Ficedula hypoleuca. Anim Behav 39:244-252. 
Anorova, N. S. 1977. Colour morphs of the Pied Flycatcher males breeding on south Moscow area. Bulletin of Moscow Society of Naturalists. Biological series 82:10-18.

Belskii, E. A. and A. G. Lyakhov. 2004. Breeding plumage coloration in Ficedula hypoleuca (Passeriformes, Muscicapidae) males from the Middle Urals. Zool Zh 83:1468-1475.

Bijlsma, R. G. and C. Both. 2014. Bonte Vliegenvangers Ficedula hypoleuca broedend in natuurlijke holtes: verschillen met nestkastbewoners. Drentse Vogels 28:114-125.

575 Brown, W. L. and E. O. Wilson. 1956. Character displacement. Systematic Zoology 5:49-64.

Butlin, R. K. and C. M. Smadja. 2018. Coupling, reinforcement, and speciation. The American Naturalist 191:155-172.

Butlin, R. K. and T. Tregenza. 1997. Is speciation no accident? Nature 387:551.

Čeh, M., M. Kilibarda, A. Lisec, and B. Bajat. 2018. Estimating the performance of random forest versus multiple regression for predicting prices of the apartments. ISPRS International Journal of Geo-Information 7:168.

Corso, A., O. Janni, M. Viganò, and L. Starnini. 2015. Atlas Pied Flycatcher: variability of identification characters. Dutch Birding 37:141-160.

Curio, E. 1959. Beiträge zur Populationsökologie des Trauerschnäppers (Ficedula h. hypoleuca Pallas). Zoologische Jahrbücher 87:185-230.

Czeszczewik, D., I. Ruczynski, K. Zieba-Schraven, J. Wisniewska, and W. Walankiewicz. 2012. The Pied and the Collared Flycatcher do not compete for microhabitats in the Bialowieza Forest. Belg J Zool 142:133-137.

Dale, S. and T. Slagsvold. 1996. Mate choice on multiple cues, decision rules and sampling strategies in female pied flycatchers. Behaviour 133:903-944.

Di Cecco, G. J. and T. C. Gouhier. 2018. Increased spatial and temporal autocorrelation of temperature under climate change. Sci Rep-Uk 8:14850.

Dobzhansky, T. 1937. Genetics and the Origin of Species.-New York, Columbia Univ. Press. Columbia University Press, New York.

Drost, R. 1936. Über das Brutkleid männlicher Trauerfliegenfanger, Muscicapa hypoleuca. Vogelzug 6:179-186.

Eggenberger, H. 1964. Über die Farbtypen der männlichen Trauerschnäpper, Ficedula hypoleuca, in der Ostschweiz. Ornithologische Beobachter 61:95-99.

Glutz von Blotzheim, U. N. and K. M. Bauer (eds). 1993. Ficedula hypoleuca (Pallas 1764) 
Mitteleuropas. Bd. 13/1: Passeriformes (4. Teil). Muscicapidae - Paridae. . AULAVerlag, Wiesbaden.

Grinkov, V. G. 1997. Male plumage variation in the pied flycatcher (Ficedula hypolleuca Pall.) and its relation with offspring quality. Possibility of phenotype diversity maintenance by disruptive selection. Dokl Akad Nauk+ 356:138-140.

Haverschmidt, F. 1973. Waarnemingen aan een populatie Bonte Vliegenvangers Ficedula hypoleuca. Limosa 46:1-20.

von Haartman, L. 1985. The biological significance of the nuptial plumage of the male Pied Flycatcher. Pp. 34-60 in V. D. Ilyichev, and V. M. Gavrilov, eds. ACTA XVIII Congressus Internationalis Ornithologici, Moscow, August 16-24, 1982. "Nauka", Moscow.

Hengl, T., M. Nussbaum, M. N. Wright, G. B. M. Heuvelink, and B. Gräler. 2018. Random forest as a generic framework for predictive modeling of spatial and spatio-temporal variables. Peerj 6:e5518.

Howard, D. J. 1993. Reinforcement: Origin, dynamics, and fate of an evolutionary hypothesis. Pp. 46-69 in R. G. Harrison, ed. Hybrid zones and the evolutionary process. Oxford University Press, New York.

Ilyina, T. A. and E. V. Ivankina. 2001. Seasonal variation of vinging activity and relative effect of the advertising behaviour of males with different plumage colour in the Pied Flycatcher Ficedula hypoleuca. Acta Ornithol 36:85-89.

Ivankina, E. V., A. B. Kerimov, V. G. Grinkov, and A. V. Bushuev. 2007. Structural and functional aspects of variation of the breeding plumage ornamentation in the male Pied Flycatcher Ficedula hypoleuca (Aves : Passeriformes). Zh Obshch Biol 68:278295.

Johansen, H. 1954. Die Vogelfauna Westsibiriens. J Ornithol 95:64-111.

Kalnay, E., M. Kanamitsu, R. Kistler, W. Collins, D. Deaven, L. Gandin, M. Iredell, S. Saha, G. White, J. Woollen, Y. Zhu, M. Chelliah, W. Ebisuzaki, W. Higgins, J. Janowiak, K. C. Mo, C. Ropelewski, J. Wang, A. Leetmaa, R. Reynolds, R. Jenne, and D. Joseph. 1996. The NCEP/NCAR 40-Year Reanalysis Project. Bulletin of the American Meteorological Society 77:437-472.

Kanamitsu, M., W. Ebisuzaki, J. Woollen, S.-K. Yang, J. J. Hnilo, M. Fiorino, and G. L. Potter. 2002. NCEP-DOE AMIP-II Reanalysis (R-2). Bulletin of the American Meteorological Society 83:1631-1644. 
Kemp, M. U., E. Emiel van Loon, J. Shamoun-Baranes, and W. Bouten. 2012. RNCEP: global weather and climate data at your fingertips. Methods Ecol Evol 3:65-70.

Kerimov, A. B., V. G. Grinkov, E. V. Ivankina, T. A. Ilyina, and A. V. Bushuev. 2014. The influence of spring temperature on the intensity of advertising behavior and basal metabolic rate in bright and pale Pied Flycatcher (Ficedula Hypoleuca) Males. Zool Zh 93:1288-1302.

640 Kral, M., T. Jarvi, and V. Bicik. 1988. Inter-specific aggression between the Collared Flycatcher and the Pied Flycatcher - the selective agent for the evolution of lightcolored male Pied Flycatcher populations. Ornis Scand 19:287-289.

Laaksonen, T., P. M. Sirkia, S. Calhim, J. E. Brommer, P. K. Leskinen, C. R. Primmer, P. Adamik, A. V. Artemyev, E. Belskii, C. Both, S. Bures, M. D. Burgess, B. Doligez, J. T. Forsman, V. Grinkov, U. Hoffmann, E. Ivankina, M. Kral, I. Krams, H. M. Lampe, J. Moreno, M. Magi, A. Nord, J. Potti, P. A. Ravussin, and L. Sokolov. 2015. Sympatric divergence and clinal variation in multiple coloration traits of Ficedula flycatchers. $J$ Evolution Biol 28:779-790.

Lehtonen, P. K., C. R. Primmer, and T. Laaksonen. 2009. Different traits affect gain of extrapair paternity and loss of paternity in the pied flycatcher, Ficedula hypoleuca. Anim Behav 77:1103-1110.

Lewontin, R. C. 1974. The genetic basis of evolutionary change. Columbia University Press New York.

Löhrl, V. H. 1965. Zwei regional und ökologisch getrennte Formen des Trauerschnäppers (Ficedula hypoleuca) in Südwestdeutschland. Bonner Zoologische Beiträge 16:268 283.

Lundberg, A. and R. V. Alatalo. 1992. The Pied Flycatcher. T \& AD Poyser Ltd., London. Miller, H. J. 2004. Tobler's first law and spatial analysis. Annals of the Association of American Geographers 94:284-289.

Noor, M. A. F. 1999. Reinforcement and other consequences of sympatry. Heredity 83:503508.

Nyholm, N. E. I. and H. E. Myhrberg. 1983. Breeding area fidelity of the pied flycatcher Ficedula hypoleuca at Ammarnäs, Swedish Lapland. Ornis Fennica 60:22-27.

Potti, J., J. L. Copete, C. Gutierrez-Exposito, and C. Camacho. 2016. Morphological and sexual traits in Atlas and Iberian Pied Flycatchers Ficedula hypoleuca speculigera and F-h. iberiae: a comparison. Bird Study 63:330-336. 
Potti, J. and S. Montalvo. 1991. Male arrival and female mate choice in Pied Flycatchers Ficedula-Hypoleuca in central Spain. Ornis Scand 22:45-54.

Probst, P., M. Wright, and A.-L. Boulesteix. 2018. Hyperparameters and tuning strategies for random forest. arXiv:1804.03515.

Qvarnstrom, A., A. M. Rice, and H. Ellegren. 2010. Speciation in Ficedula flycatchers. Philos T R Soc B 365:1841-1852.

Ristow, D. 1975. Der Trauerschnäpper (Ficedula hypoleuca) in der Eifel und im Kottenforst bei Bonn. Kilda-Verlag, Greven.

Roskaft, E. and T. Jarvi. 1983. Male plumage color and mate choice of female Pied Flycatchers Ficedula hypoleuca. Ibis 125:396-400.

Roskaft, E., T. Jarvi, N. E. I. Nyholm, M. Virolainen, W. Winkel, and H. Zang. 1986. Geographic variation in secondary sexual plumage color characteristics of the male Pied Flycatcher. Ornis Scand 17:293-298.

Saetre, G. P., S. Dale, and T. Slagsvold. 1994. Female Pied Flycatchers prefer brightly colored males. Anim Behav 48:1407-1416.

Saetre, G. P., T. Moum, S. Bures, M. Kral, M. Adamjan, and J. Moreno. 1997. A sexually selected character displacement in flycatchers reinforces premating isolation. Nature 387:589-592.

Saetre, G. P. and S. A. Saether. 2010. Ecology and genetics of speciation in Ficedula flycatchers. Mol Ecol 19:1091-1106.

Sangster, G., J. M. Collinson, A. J. Helbig, A. G. Knox, and D. T. Parkin. 2004. Taxonomic recommendations for British birds: second report. Ibis 146:153-157.

Servedio, M. R. 2004. The what and why of research on reinforcement. Plos Biol 2:e420e420.

Servedio, M. R. and M. A. F. Noor. 2003. The role of reinforcement in speciation: theory and data. Annual Review of Ecology, Evolution, and Systematics 34:339-364.

Sirkia, P. M., P. Adamik, A. V. Artemyev, E. Belskii, C. Both, S. Bures, M. Burgess, A. V. Bushuev, J. T. Forsman, V. Grinkov, D. Hoffmann, A. Jarvinen, M. Kral, I. Krams, H. M. Lampe, J. Moreno, M. Magi, A. Nord, J. Potti, P. A. Ravussin, L. Sokolov, and T. Laaksonen. 2015. Fecundity selection does not vary along a large geographical cline of trait means in a passerine bird. Biol J Linn Soc 114:808-827.

Sirkia, P. M. and T. Laaksonen. 2009. Distinguishing between male and territory quality: females choose multiple traits in the pied flycatcher. Anim Behav 78:1051-1060. 
Sirkia, P. M., M. Virolainen, and T. Laaksonen. 2010. Melanin coloration has temperaturedependent effects on breeding performance that may maintain phenotypic variation in a passerine bird. J Evolution Biol 23:2385-2396.

Sternberg, H. 1964. Untersuchungen über die Farbtypenzugehörigkeit der männlichen Trauerschnäpper, Ficedula hypoleuca, im Schweizerischen Mittelland. Ornithologische Beobachter 61:90-94.

Sternberg, H., V. G. Grinkov, E. V. Ivankina, T. A. Ilyina, A. B. Kerimov, and A. Schwarz. 2002. Evaluation of the size and composition of nonbreeding surplus in a Pied Flycatcher Ficedula hypoleuca population: Removal experiments in Germany and Russia. Ardea 90:461-470.

Trettau, W. 1952/53. Planberingung des Trauerfliegenschnäppers (Muscícapa hypoleuca) in Hessen. Vogelwarte - Zeitschrift für Vogelkunde 16:89-95.

Trettau, W. and F. Merkel. 1943. Ergebnisse einer Planberingung des Trauerfliegenschnäppers (Muscicapa hypoleuca Pallas) in Schlesien. Vogelzug 14:77-90.

Tzedakis, P. C., B. C. Emerson, and G. M. Hewitt. 2013. Cryptic or mystic? Glacial tree refugia in northern Europe. Trends Ecol Evol 28:696-704.

Vabishchevich, A. P. and N. A. Formozov. 2010. Song variability in Pied Flycatchers Ficedula hypoleuca: impact of the sympatry with Collared Flycatchers F. albicollis. Acta Ornithol 45:189-202.

Vysotsky, V. G. 1995. Coloring of male pied flycatchers and its relationship with other characters. Ornitologiya 26:28-32.

Wager, S., T. Hastie, and B. Efron. 2014. Confidence Intervals for random forests: the jackknife and the infinitesimal jackknife. Journal of machine learning research : JMLR 15:1625-1651.

Walankiewicz, W., C. Mitrus, D. Czeszczewik, and P. M. Jablonski. 1997. Is the Pied Flycatcher Ficedula hypoleuca overcompeted by the Collared Flycatcher Ficedula albicollis in the natural forest of Bialowieza? Acta Ornithol 2:213-217.

Wickham, H. 2016. ggplot2: Elegant graphics for data analysis. Springer-Verlag, New York. Winkel, W., D. Richter, and R. Berndt. 1970. Über Beziehungen zwischen Farbtyp und Lebensalter männlicher Trauerschnäpper (Ficedula hypoleuca). Vogelwelt 91:161170. 
Winkel, W. and D. Winkel. 1984. Polygynie des Trauerschnäppers (Ficedula hypoleuca) am Westrand seines Areals in Mitteleuropa. J Ornithol 125:1-14.

Wright, M. N. and A. Ziegler. 2017. ranger: A fast implementation of random forests for high dimensional data in C++ and R. Journal of Statistical Software 77:17.

Zang, H. 1975. Populationsstudien am Trauerschnäpper (Ficedula hypoleuca) im Bergwald des Harzes als einem suboptimalen Habitat. Vogelwelt 96:161-184. 

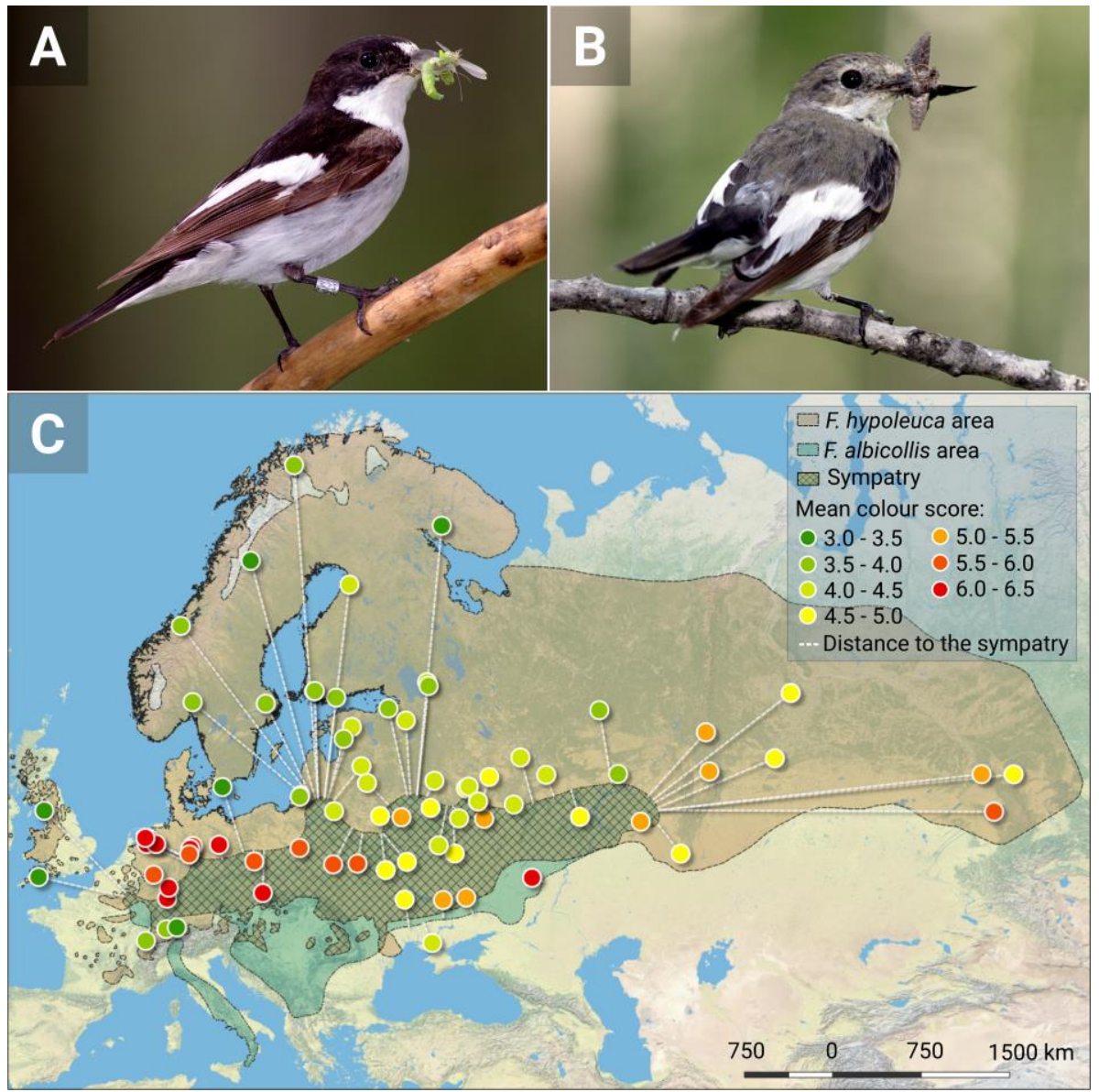

Fig. 1. The variability of the male breeding plumage colour and the mean colour score in populations of the Pied Flycatcher (F. hypoleuca).

(A) The contrast-coloured male (black morph). (B) The less bright male (brown morph). (C) The mean colour score in populations breeding in different parts of the Pied Flycatcher $F$. hypoleuca range. For each observation point, the distance to the border of the Collared Flycatcher $F$. albicollis is shown. Photos (A) and (B) credits: Vladimir G. Grinkov. Map source: the U.S. National Park Service (NPS) Natural Earth physical map. 


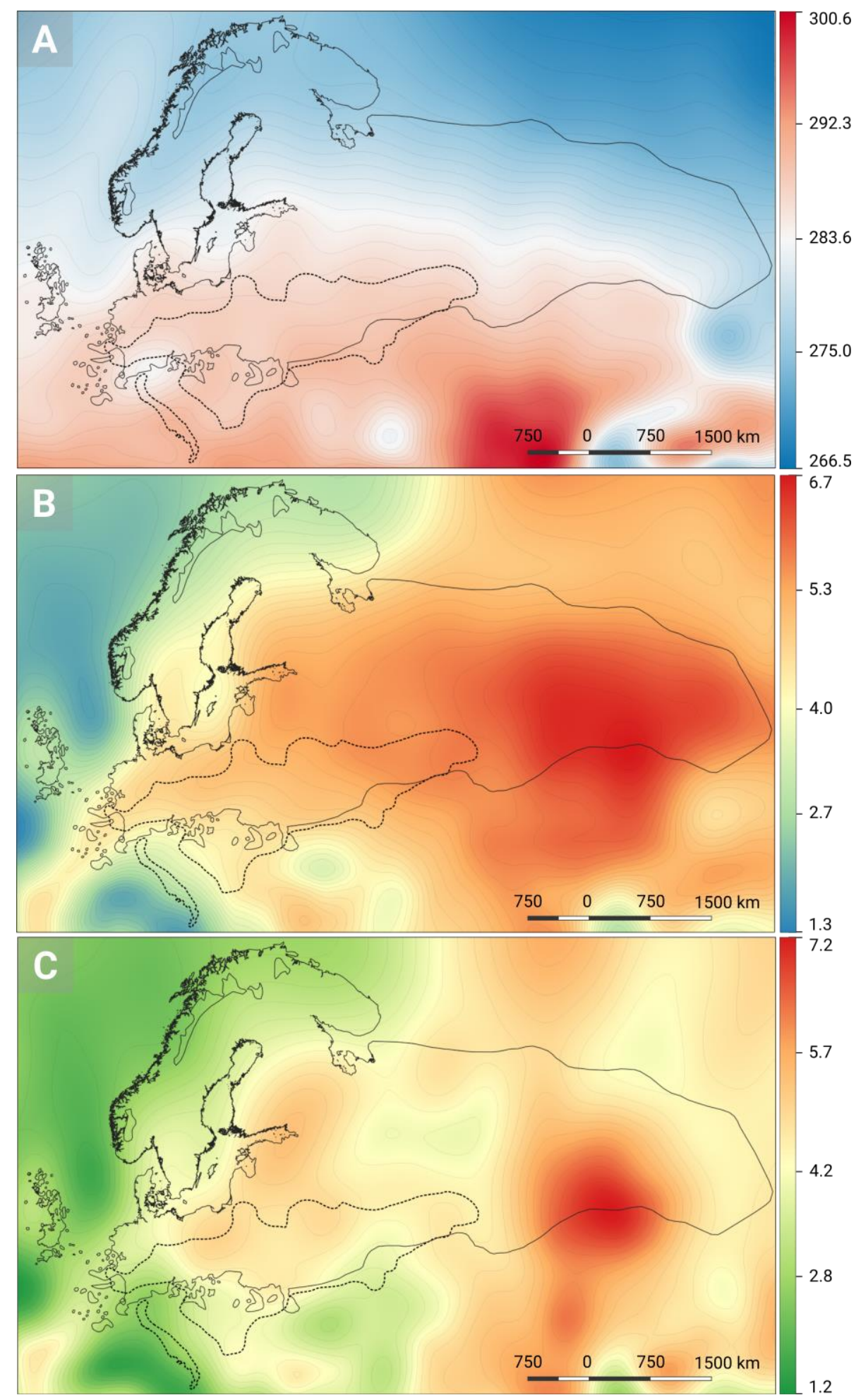

Fig. 2. Thermal characteristics of the territories covered by the breeding ranges of the two species of Ficedula flycatchers.

The images show (A) the mean daily maximum temperature in Kelvin, (B) the standard deviation of the daily maximum temperature, and (C) the standard deviation of the maximum temperature on May 1 . The F. hypoleuca area is drawn with a solid line, the $F$. albicollis area is drawn with a dashed line. Each colour links to the value of the corresponding thermal characteristics (the key is on the right of each image). The hairlines 
bioRxiv preprint doi: https://doi.org/10.1101/515916; this version posted January 23, 2019. The copyright holder for this preprint (which was not certified by peer review) is the author/funder. All rights reserved. No reuse allowed without permission.

connect the areas with the same values of the shown characteristic (for example, in the figure (A) these are isotherms). 



Fig. 3. The results of the $\mathbf{1 0}$-fold cross-validation procedure for $\mathbf{1 0 0}$ repetitions.

(A) Prediction performance of models calculated as the root mean squared error (RMSE) with sequentially reduced number of predictors. (B) The removal order of predictors and its frequency in percent (\%), showing at what step and how often the predictors obtaining the lowest variable importance value were excluded from the models. (C) The variable importance values measured as the variance of the responses are given for all predictors (the variable importance values on the ordinate axis are converted by a decimal logarithm). The figure parts (A) and (C) show the median (the line across the box), the interquartile range (IQR, the box), the positive and negative 1.5*IQR extension of the IQR (the vertical dotted line). The small black circles represent outliers from the latter range. A horizontal line with downward serifs at the ends connects the compared values for which significance levels of Student's t-test (two-tailed) shown as following: ns for $p>0.05$; for $p<0.05$; **

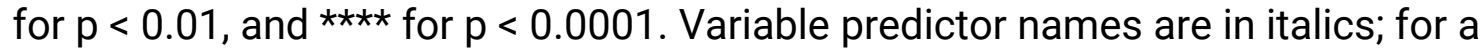
description, please see the material and methods. 


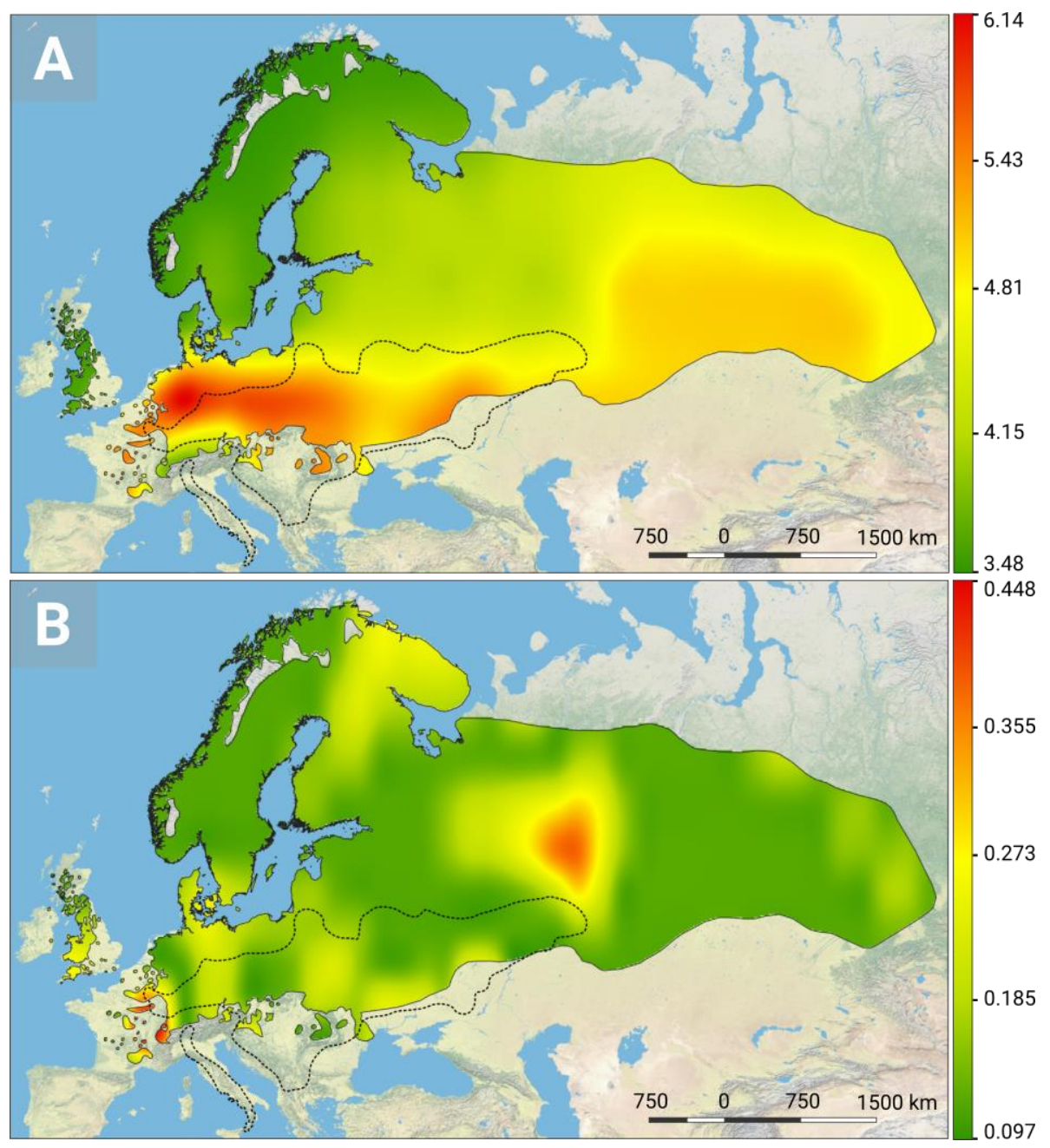

Fig. 4. Reconstruction of the phenotypic structure of the $F$. hypoleuca populations for the entire breeding range.

(A) Mean colour score predicted by the final random forest model. (B) Accuracy of the predicted values (the standard error of the predictions, see also Fig. S2). In the figure parts, the colour links to the value of the corresponding characteristic shown (the key is on the right of each part). 


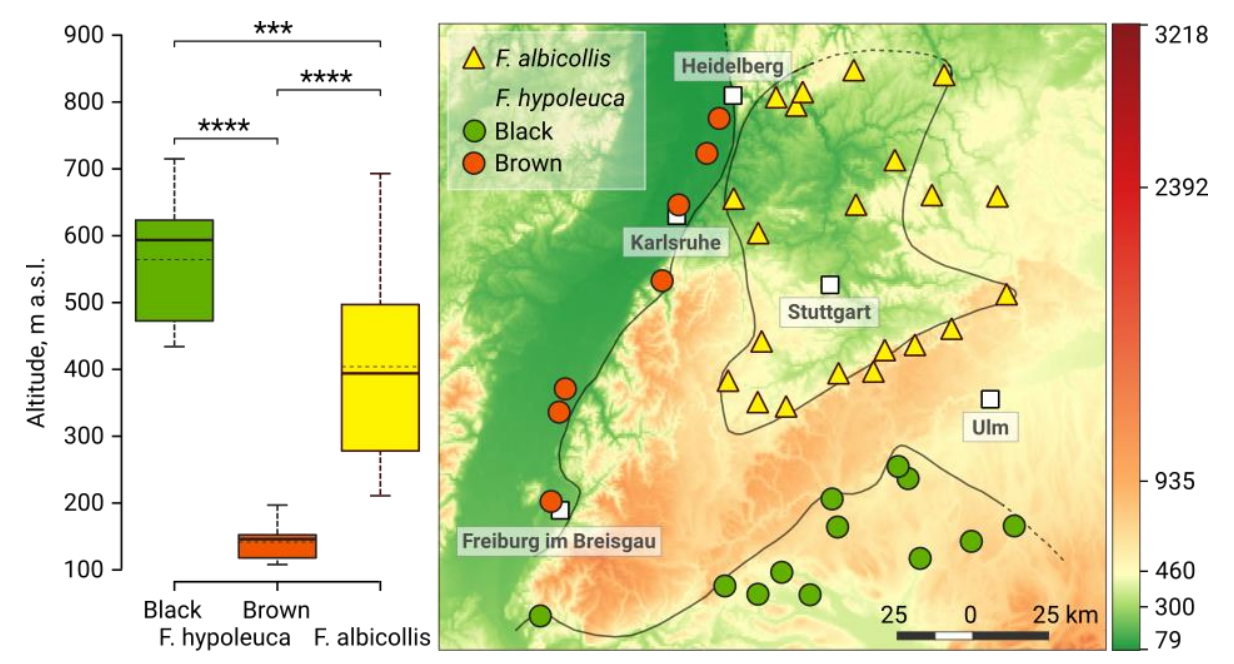

Fig. 5. Small-scale spatial segregation between two species of the Ficedula flycatcher in south-west Germany, depending on the elevation above sea level.

Reprocessed data of figure 2 (page 271) of the H. Löhrl publication in Bonner Zoologische Beiträge (Löhrl 1965) are shown. On the map, the colour indicates the height above sea level (altitude) in meters (according to the color rump on the right of the map) and the location of the nests of the two species of Ficedula flycatchers. The graph compares the height of the nest locations above sea level. The graph shows the median (the solid line across the box), the mean (the dashed line across the box), the interquartile range (IQR, the box), the positive and negative 1.5*IQR extension of the IQR (the vertical dotted line). A horizontal line with downward serifs at the ends connects the compared values for which the significance levels of Student's t-test (two-tailed) are shown as following: *** for $p<$ 0.001 , and $\star \star \star \star$ for $p<0.0001$. 


\section{Supplementary Materials.}


Fig. S1. The relationship between the mean colour score (response variable) and all predictors.

The scatterplots are presented for each predictor separately (the predictor name is written in italics under the $x$-axis), the linear (black dashed line) and non-linear (blue dashed curve) regressions are drawn; for each regression, the coefficient of determination $\left(R^{2}\right)$ and the significance level are given (indicated in black and blue font, respectively). 


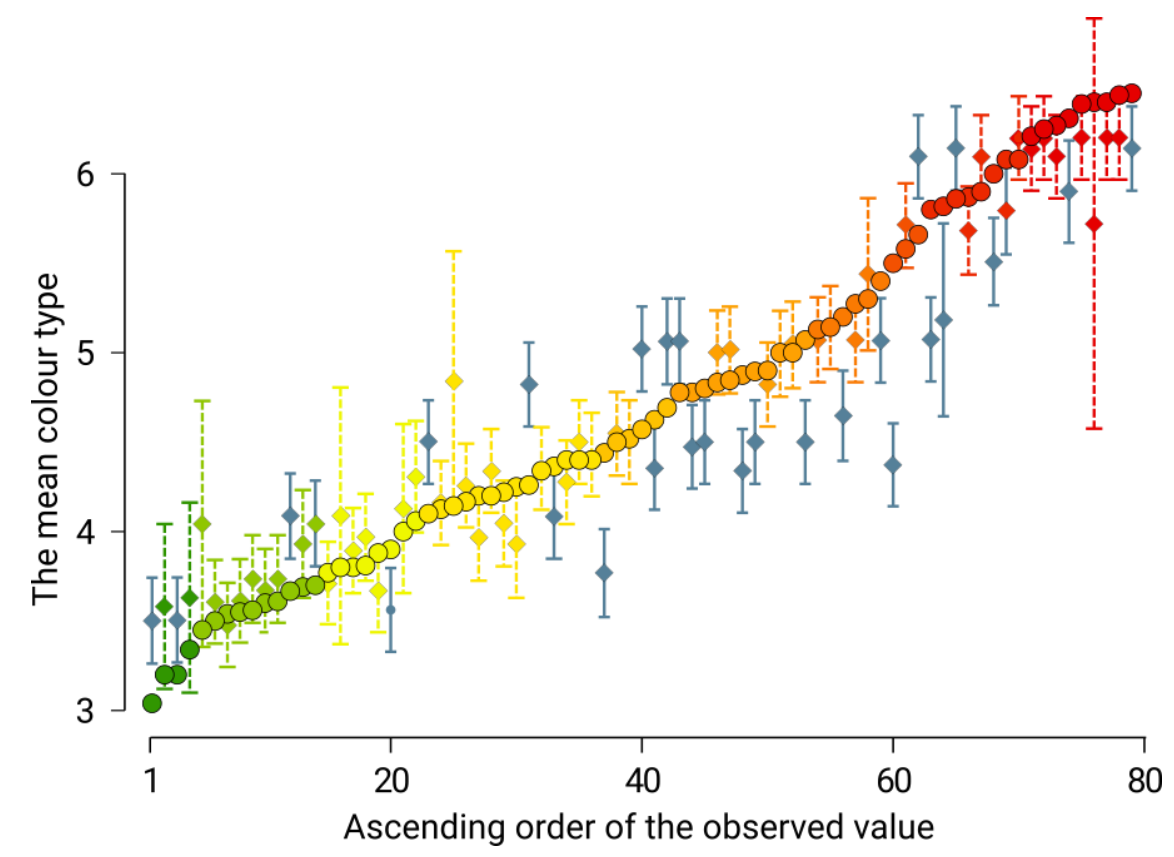

805 Fig. S2. Comparison of observed and predicted values of mean colour score of male breeding plumage in the $F$. hypoleuca populations.

The observed values are drawn in circles, the corresponding predicted values are drawn in diamonds; for each predicted value, a dashed vertical line indicates a $95 \%$ confidence interval $(95 \% \mathrm{Cl})$. Dark blue colour indicates such predictions that do not contain the observed value in the $95 \% \mathrm{Cl}$. 


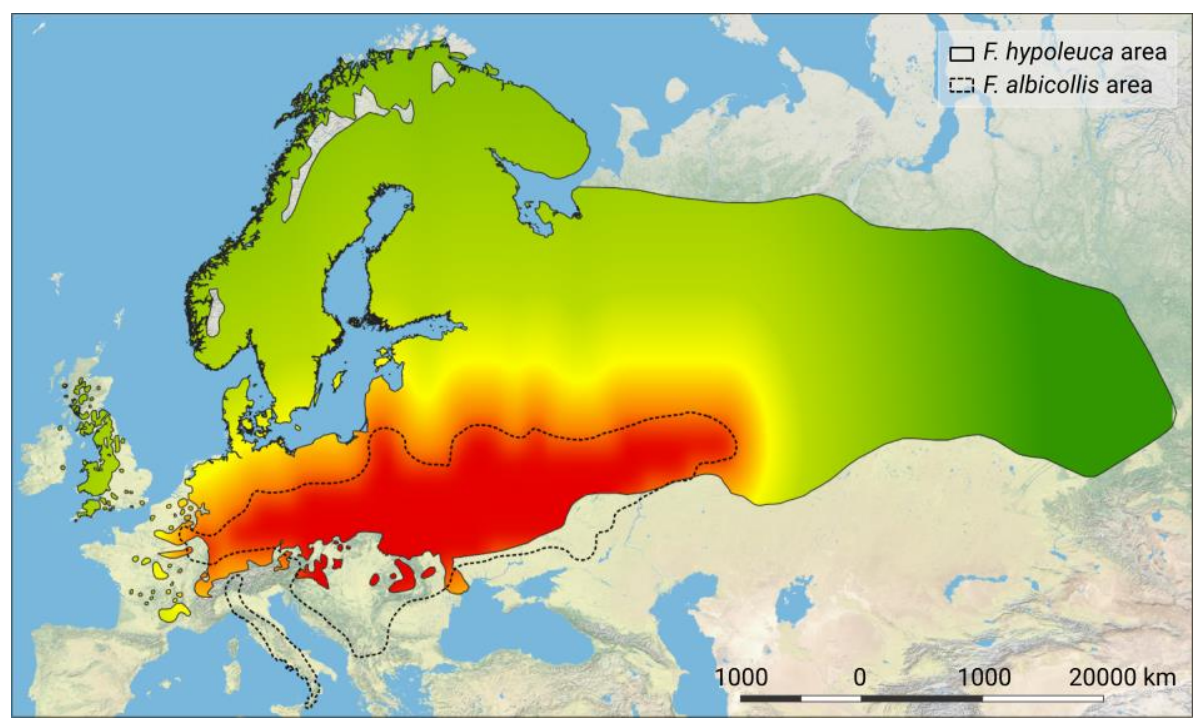

Fig. S3. The hypothetical phenotypic structure of $F$. hypoleuca populations is drawn as if it was determined by the distance from the nesting range of $F$. albicollis.

815 The transition from red through yellow to green corresponds to a change in the proportions of different morphs in the populations of $F$. hypoleuca from the most frequent brown through the intermediate to the most frequent black, respectively. 
bioRxiv preprint doi: https://doi.org/10.1101/515916; this version posted January 23, 2019. The copyright holder for this preprint (which was not certified by peer review) is the author/funder. All rights reserved. No reuse allowed without permission.

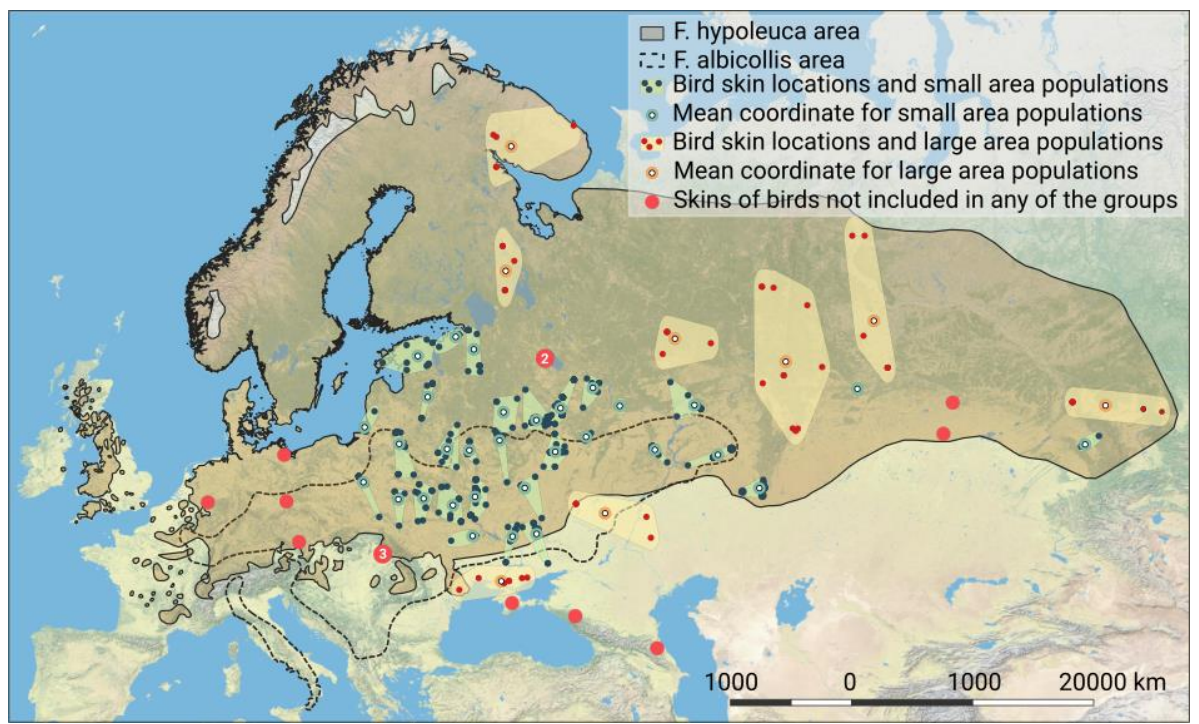

$820 \quad$ Fig. S4. "Populations" formed from bird skins which were studied in 11 museums. The average population coordinate is the observation point used in the calculations (for summary data, please, see Table S2). 
Table S1.

The mean colour of males' breeding plumage in the Pied Flycatcher Ficedula hypoleuca populations.

\begin{tabular}{|c|c|c|c|c|c|c|c|}
\hline \# & Longitude & Latitude & $\begin{array}{l}\text { Mean } \\
\text { colour } \\
\text { type }\end{array}$ & $\begin{array}{l}\text { Sample } \\
\text { size }\end{array}$ & Location & Country & Source \\
\hline 1 & 17.36 & 49.64 & 6.08 & 50 & Moravia-Jeseníky & $\begin{array}{l}\text { Czech } \\
\text { Republic }\end{array}$ & $\begin{array}{l}\text { Laaksonen et al. 2015; } \\
\text { Sirkia et al. } 2015\end{array}$ \\
\hline 2 & 24.95 & 58.15 & 3.81 & 73 & Kilingi-Nõmme & Estonia & $\begin{array}{l}\text { Laaksonen et al. 2015; } \\
\text { Sirkia et al. } 2015\end{array}$ \\
\hline 3 & 22.16 & 60.43 & 3.56 & 408 & Ruissalo & Finland & $\begin{array}{l}\text { Laaksonen et al. 2015; } \\
\text { Sirkia et al. } 2015\end{array}$ \\
\hline 4 & 22.24 & 60.44 & 3.61 & 1207 & Turku & Finland & von Haartman 1985 \\
\hline 5 & 24.25 & 60.14 & 3.80 & 117 & Siuntio & Finland & Roskaft et al. 1986 \\
\hline 6 & 25.50 & 65.02 & 4.44 & 48 & Oulu & Finland & Laaksonen et al. 2015 \\
\hline 7 & 7.09 & 50.74 & 5.86 & 66 & Bonn & Germany & Ristow 1975 \\
\hline 8 & 7.29 & 52.52 & 6.40 & 416 & Lingen & Germany & Winkel and Winkel 1984 \\
\hline 9 & 7.32 & 52.53 & 6.39 & 806 & Lingen & Germany & $\begin{array}{l}\text { Handbuch der Vögel } \\
\text { Mitteleuropas, } 1993\end{array}$ \\
\hline 10 & 8.36 & 49.30 & 6.21 & 42 & Harthausen & Germany & $\begin{array}{l}\text { Laaksonen et al. 2015; } \\
\text { Sirkia et al. } 2015\end{array}$ \\
\hline 11 & 8.51 & 49.96 & 6.45 & 49 & $\begin{array}{l}\text { Mönchbruch, } \\
\text { Hessen }\end{array}$ & Germany & Trettau 1952/53 \\
\hline 12 & 10.43 & 51.94 & 5.66 & 44 & $\begin{array}{l}\text { Goslar, Harz, Lower } \\
\text { Saxony }\end{array}$ & Germany & Zang 1975 \\
\hline 13 & 10.52 & 52.25 & 6.27 & 536 & Braunschweig & Germany & Winkel et al. 1970 \\
\hline 14 & 10.78 & 52.42 & 5.90 & 1583 & $\begin{array}{l}\text { Wolfsburg, Lower } \\
\text { Saxony }\end{array}$ & Germany & Sternberg et al. 2002 \\
\hline 15 & 13.24 & 52.49 & 6.31 & 15 & Berlin, Grunewald & Germany & Curio 1959 \\
\hline 16 & 27.15 & 55.89 & 4.34 & 60 & Kraslava & Latvia & $\begin{array}{l}\text { Laaksonen et al. 2015; } \\
\text { Sirkia et al. } 2015\end{array}$ \\
\hline 17 & 9.65 & 63.33 & 3.90 & 166 & Songli & Norway & Roskaft et al. 1986 \\
\hline 18 & 10.75 & 59.92 & 3.77 & 72 & Oslo & Norway & $\begin{array}{l}\text { Laaksonen et al. 2015; } \\
\text { Sirkia et al. } 2015\end{array}$ \\
\hline 19 & 20.29 & 69.36 & 3.54 & 95 & Skibotn & Norway & $\begin{array}{l}\text { Laaksonen et al. 2015; } \\
\text { Sirkia et al. } 2015\end{array}$ \\
\hline 20 & 16.55 & 51.52 & 5.58 & 105 & Jemielno, Silesia & Poland & Trettau and Merkel 1943 \\
\hline 21 & 20.83 & 55.16 & 3.69 & 459 & Courish spit & Russia & Vysotsky 1995 \\
\hline 22 & 32.80 & 60.85 & 4.22 & 217 & $\begin{array}{l}\text { Scientific field } \\
\text { station "Mayachino" }\end{array}$ & Russia & $\begin{array}{l}\text { Laaksonen et al. 2015; } \\
\text { Sirkia et al. } 2015\end{array}$ \\
\hline 23 & 32.94 & 60.68 & 3.70 & 93 & $\begin{array}{l}\text { Ladoga } \\
\text { Ornithological } \\
\text { Station "Gumbaricy" }\end{array}$ & Russia & Grinkov 1997 \\
\hline 24 & 33.89 & 52.45 & 4.26 & 110 & $\begin{array}{l}\text { Bryansky Les } \\
\text { Nature Reserve }\end{array}$ & Russia & Own data \\
\hline 25 & 35.81 & 53.98 & 4.40 & NA & Ugra National Park & Russia & $\begin{array}{c}\text { Vabishchevich and } \\
\text { Formozov } 2010 \\
\end{array}$ \\
\hline 26 & 36.72 & 55.70 & 4.40 & 1403 & Zvenigorod & Russia & Ivankina et al. 2007 \\
\hline 27 & 37.57 & 54.90 & 4.80 & 1631 & Moscow region & Russia & Anorova 1977 \\
\hline
\end{tabular}




\begin{tabular}{|c|c|c|c|c|c|c|c|}
\hline 28 & 37.60 & 54.90 & 4.10 & NA & $\begin{array}{l}\text { PTS Natural } \\
\text { Biosphere Reserve }\end{array}$ & Russia & $\begin{array}{l}\text { Vabishchevich and } \\
\text { Formozov } 2010\end{array}$ \\
\hline 29 & 59.34 & 56.49 & 5.13 & 376 & Ekaterinburg & Russia & Belskii and Lyakhov 2004 \\
\hline 30 & 84.95 & 56.35 & 5.40 & 1770 & Tomsk & Russia & Own data \\
\hline 31 & 13.55 & 55.67 & 3.45 & 54 & Vombs fure & Sweden & Laaksonen et al. 2015 \\
\hline 32 & 16.21 & 65.95 & 3.20 & 403 & Ammarnäs & Sweden & $\begin{array}{l}\text { Nyholm and Myhrberg } \\
1983\end{array}$ \\
\hline 33 & 17.63 & 59.85 & 3.55 & 408 & Uppsala & Sweden & Lundberg and Alatalo 1992 \\
\hline 34 & 6.35 & 46.63 & 3.88 & 81 & Vaud & Switzerland & $\begin{array}{l}\text { Laaksonen et al. 2015; } \\
\text { Sirkia et al. } 2015\end{array}$ \\
\hline 35 & 8.29 & 47.39 & 3.60 & 34 & Aagau-Zürich & Switzerland & Sternberg 1964 \\
\hline 36 & 9.27 & 47.49 & 3.50 & 73 & $\begin{array}{l}\text { Bischofszell, } \\
\text { Thurgau }\end{array}$ & Switzerland & Eggenberger 1964 \\
\hline 37 & 6.31 & 52.88 & 6.44 & 112 & Diever - Doldersum & $\begin{array}{l}\text { The } \\
\text { Netherlands }\end{array}$ & Bijlsma and Both 2014 \\
\hline 38 & 6.42 & 52.52 & 6.25 & 77 & Ommen & $\begin{array}{l}\text { The } \\
\text { Netherlands }\end{array}$ & Haverschmidt 1973 \\
\hline 39 & 6.60 & 52.86 & 6.08 & 440 & Drenthe & $\begin{array}{l}\text { The } \\
\text { Netherlands }\end{array}$ & $\begin{array}{l}\text { Laaksonen et al. 2015; } \\
\text { Sirkia et al. } 2015\end{array}$ \\
\hline 40 & -3.73 & 50.60 & 3.34 & 88 & East Dartmoor & $\begin{array}{l}\text { United } \\
\text { Kingdom }\end{array}$ & $\begin{array}{l}\text { Laaksonen et al. 2015; } \\
\text { Sirkia et al. } 2015\end{array}$ \\
\hline 41 & -3.20 & 54.40 & 3.04 & 489 & Cumbria & $\begin{array}{l}\text { United } \\
\text { Kingdom }\end{array}$ & Lundberg and Alatalo 1992 \\
\hline
\end{tabular}




\section{Table S2.}

The observation points for "populations" formed by the bird skins from museum collections.

The mean colour type for population with ID 4, indicated in square brackets, was excluded from the analysis (see the materials and methods for the explanation). The column "Populations" contains identifiers of populations, denoted as L-1, L-2, etc. for large

835 populations and S-1, S-2, etc. for small populations, respectively (please also see Fig. S4 and Data S1).

\begin{tabular}{|c|c|c|c|c|c|c|}
\hline ID & Longitude & Latitude & $\begin{array}{l}\text { Mean colour } \\
\text { type }\end{array}$ & $\begin{array}{l}\text { Standard } \\
\text { deviation }\end{array}$ & $\begin{array}{l}\text { Number of the } \\
\text { bird skins }\end{array}$ & Populations \\
\hline 1 & 33.29 & 46.49 & 4.14 & 1.46 & 7 & $L-1$ \\
\hline 2 & 42.67 & 50.55 & 6.40 & 0.89 & 5 & $\mathrm{~L}-2$ \\
\hline 3 & 34.17 & 67.26 & 3.20 & 1.10 & 5 & $\mathrm{~L}-3$ \\
\hline 4 & 33.68 & 62.50 & [2.17] & 0.41 & 6 & $L-4$ \\
\hline 5 & 49.00 & 59.54 & 3.80 & 1.10 & 5 & $L-5$ \\
\hline 6 & 59.02 & 58.47 & 5.27 & 1.56 & 11 & $L-6$ \\
\hline 7 & 67.00 & 60.35 & 5.00 & 1.26 & 6 & $L-7$ \\
\hline 8 & 87.96 & 56.34 & 4.57 & 0.98 & 7 & $L-8$ \\
\hline 9 & 20.81 & 52.30 & 5.59 & 1.28 & 17 & $S-1$ \\
\hline 10 & 20.92 & 55.24 & 4.25 & 1.06 & 12 & S-2 \\
\hline 11 & 23.97 & 51.35 & 6.00 & 1.20 & 8 & S-3 \\
\hline 12 & 24.05 & 54.37 & 3.91 & 0.94 & 11 & S-4 \\
\hline 13 & 26.25 & 51.40 & 5.82 & 1.47 & 11 & $S-5$ \\
\hline 14 & 26.62 & 56.76 & 4.13 & 1.36 & 8 & S-6 \\
\hline 15 & 25.73 & 58.73 & 4.20 & 1.23 & 10 & $S-7$ \\
\hline 16 & 28.91 & 51.01 & 4.69 & 1.11 & 13 & S-8 \\
\hline 17 & 28.38 & 54.10 & 4.63 & 1.60 & 8 & $S-9$ \\
\hline 18 & 29.16 & 59.63 & 3.67 & 0.82 & 6 & $S-10$ \\
\hline 19 & 30.69 & 49.23 & 4.78 & 1.20 & 9 & $S-11$ \\
\hline 20 & 30.90 & 51.50 & 4.85 & 1.09 & 39 & $S-12$ \\
\hline 21 & 30.39 & 54.04 & 5.50 & 0.93 & 8 & $S-13$ \\
\hline 22 & 30.80 & 59.05 & 4.36 & 1.21 & 11 & $S-14$ \\
\hline 23 & 34.30 & 49.21 & 5.14 & 1.10 & 14 & S-15 \\
\hline 24 & 33.12 & 54.55 & 4.88 & 1.81 & 8 & S-16 \\
\hline 25 & 33.48 & 56.00 & 4.20 & 1.79 & 5 & S-17 \\
\hline 26 & 36.48 & 49.36 & 5.30 & 1.06 & 10 & S-18 \\
\hline 27 & 35.41 & 51.98 & 4.90 & 1.79 & 10 & S-19 \\
\hline 28 & 36.45 & 55.60 & 4.94 & 1.30 & 17 & S-20 \\
\hline 29 & 38.17 & 53.95 & 5.07 & 1.49 & 14 & S-21 \\
\hline 30 & 38.64 & 56.21 & 4.50 & 1.49 & 48 & S-22 \\
\hline 31 & 40.95 & 54.73 & 4.50 & 1.38 & 6 & S-23 \\
\hline 32 & 41.58 & 57.21 & 4.17 & 0.41 & 6 & S-24 \\
\hline
\end{tabular}


bioRxiv preprint doi: https://doi.org/10.1101/515916; this version posted January 23, 2019. The copyright holder for this preprint (which was not certified by peer review) is the author/funder. All rights reserved. No reuse allowed without permission.

\begin{tabular}{|l|l|l|l|l|l|l|}
33 & 44.00 & 56.32 & 4.40 & 1.34 & 5 & $\mathrm{~S}-25$ \\
\hline 34 & 47.18 & 54.06 & 4.78 & 1.72 & 9 & $\mathrm{~S}-26$ \\
\hline 35 & 52.89 & 53.79 & 5.25 & 1.28 & 8 & $\mathrm{~S}-27$ \\
\hline 36 & 50.76 & 56.36 & 4.00 & 1.63 & 13 & $\mathrm{~S}-28$ \\
\hline 37 & 56.64 & 51.97 & 4.83 & 1.40 & 12 & $\mathrm{~S}-29$ \\
\hline 38 & 65.50 & 57.17 & 5.00 & 1.58 & 5 & $\mathrm{~S}-30$ \\
\hline 39 & 86.11 & 54.34 & 5.80 & 1.30 & 5 & $\mathrm{~S}-31$ \\
\hline
\end{tabular}

840 
Data S1. The list of bird skins stored in museum collections and used to calculate the mean breeding plumage color score of males in the Pied Flycatcher populations.

\begin{tabular}{|c|c|c|c|c|c|c|c|c|}
\hline $\begin{array}{c}\text { Row } \\
\text { ID }\end{array}$ & Bird skin ID & $\begin{array}{c}\text { Colour } \\
\text { type }\end{array}$ & Latitude.S-N & Longitude.W-E & $\begin{array}{c}\text { Population } \\
\text { ID }\end{array}$ & Museum & Location (transliterated) & Location (translated) \\
\hline 1 & R-11766 & 2 & 53.849 & 13.694 & $\mathrm{~N} / \mathrm{A}$ & 7 & Anklam, Pomeraniya & Anklam, Pomerania \\
\hline 2 & R-109136 & 5 & 52.431 & 56.991 & S-29 & 7 & YUzhnyj Ural, verhov'ya reki Malaya Suren' & $\begin{array}{l}\text { Southern Ural, upper reaches of the Malaya } \\
\text { Suren river }\end{array}$ \\
\hline 3 & R-109144 & 3 & 52.001 & 57.034 & S-29 & 7 & YUzhnyj Ural, Kasmarka & South Ural, Kasmark \\
\hline 4 & R-109135 & 5 & 52.001 & 57.034 & S-29 & 7 & YUzhnyj Ural, Kasmarka & South Ural, Kasmark \\
\hline 5 & R-109145 & 3 & 52.001 & 57.034 & S-29 & 7 & YUzhnyj Ural, Kasmarka & South Ural, Kasmark \\
\hline 6 & R-29249 & 4 & 54.108 & 54.122 & S-27 & 7 & Belebejskij rajon & Belebey district \\
\hline 7 & R-109142 & 6 & 54.108 & 54.122 & S-27 & 7 & Belebejskij rajon & Belebey district \\
\hline 8 & R-107465 & 5 & 61.038 & 60.973 & L-6 & 7 & Verhov'ya reki Malaya Sos'va & The upper river Malaya Sosva \\
\hline 9 & $R-50644$ & 6 & 61.794 & 57.923 & L-6 & 7 & Verhov'ya Pechory & Upper Pechora \\
\hline 10 & $\mathrm{R}-83501$ & 4 & 56.235 & 40.681 & S-24 & 7 & Vladimirskaya oblast', selo Nesterkovo & Vladimir region, village Nesterkovo \\
\hline 11 & $\mathrm{R}-60274$ & 6 & 58.219 & 62.315 & L-6 & 7 & Ekaterinburgskaya oblast' & Yekaterinburg region \\
\hline 12 & $R-13750$ & 4 & 57.012 & 42.003 & S-24 & 7 & Ivanovskaya oblast' & Ivanovo region \\
\hline 13 & R-51815 & 4 & 59.673 & 66.055 & L-7 & 7 & Irtysh, verhov'ya reki Kondy, ozero Orditur (?) & $\begin{array}{l}\text { Irtysh, headwaters of the river Konda, Orditur } \\
\text { lake (?) }\end{array}$ \\
\hline 14 & $\mathrm{R}-40007$ & 3 & 58.669 & 37.275 & $\mathrm{~N} / \mathrm{A}$ & 7 & Kalininskaya oblast', Ves'egonskij rajon & Kalinin region, Vesyegonsky district \\
\hline 15 & $\mathrm{R}-40006$ & 2 & 58.669 & 37.275 & $\mathrm{~N} / \mathrm{A}$ & 7 & Kalininskaya oblast', Ves'egonskij rajon & Kalinin region, Vesyegonsky district \\
\hline 16 & R-40008 & 6 & 57.123 & 35.466 & $\mathrm{~S}-20$ & 7 & Kalininskaya oblast', Lihoslavskij rajon & Kalinin region, Likhoslav district \\
\hline 17 & $\mathrm{R}-88770$ & 2 & 63.523 & 33.402 & L-4 & 7 & Kareliya & Karelia \\
\hline 18 & R-88769 & 2 & 63.523 & 33.402 & L-4 & 7 & Kareliya & Karelia \\
\hline 19 & $\mathrm{R}-89750$ & 5 & 54.788 & 87.356 & $\mathrm{~S}-31$ & 7 & Kemerovskaya oblast', Pron'evskij rajon & Kemerovo region, Pronevsky district \\
\hline 20 & $\mathrm{R}-11737$ & 4 & 57.452 & 41.499 & S-24 & 7 & Kostromskaya oblast', Plyos & Kostroma region, Plyos \\
\hline 21 & $\mathrm{R}-97950$ & 5 & 56.163 & 91.389 & $\mathrm{~L}-8$ & 7 & Krasnoyarskij kraj, Kozul'skij rajon & Krasnoyarsk Territory, Kozulsky District \\
\hline 22 & R-41100 & 4 & 67.661 & 32.561 & L-3 & 7 & Laplandskij zapovednik & Lapland Reserve \\
\hline 23 & 7554 & 4 & 66.538 & 32.823 & $\mathrm{~L}-3$ & 4 & Louhskij rajon, CHyornaya rechka & Loukhsky district, Black River \\
\hline 24 & $\mathrm{~N} / \mathrm{A}$ & 2 & 66.538 & 32.823 & L-3 & 4 & Louhskij rajon, CHyornaya rechka & Loukhsky district, Black River \\
\hline 25 & $\mathrm{R}-89460$ & 4 & 55.727 & 36.212 & $\mathrm{~S}-20$ & 7 & Moskovskaya oblast', Arhangel'skoe & Moscow region, Arkhangelsk \\
\hline 26 & R-75466 & 7 & 55.741 & 36.501 & $\mathrm{~s}-20$ & 7 & $\begin{array}{l}\text { Moskovskaya oblast', Gluboko-Istrinskij } \\
\text { zapovednik }\end{array}$ & Moscow region, Gluboko-Istrinsky reserve \\
\hline 27 & $\mathrm{R}-36697$ & 2 & 56.315 & 38.132 & $\mathrm{~S}-22$ & 7 & Moskovskaya oblast', Zagorskij rajon & Moscow region, Zagorsky district \\
\hline 28 & $R-117099$ & 3 & 55.865 & 37.836 & S-22 & 7 & Moskovskaya oblast', Losinyj ostrov & Moscow region, Losiny island \\
\hline 29 & $\mathrm{R}-60277$ & 4 & 55.495 & 36.039 & S-20 & 7 & Moskovskaya oblast', Mozhajskij rajon & Moscow region, Mozhaisky district \\
\hline 30 & $\mathrm{R}-6028$ & 3 & 55.495 & 36.039 & S-20 & 7 & Moskovskaya oblast', Mozhajskij rajon & Moscow region, Mozhaisky district \\
\hline 31 & $\mathrm{R}-83497$ & 4 & 55.495 & 36.039 & S-20 & 7 & Moskovskaya oblast', Mozhajskij rajon & Moscow region, Mozhaisky district \\
\hline 32 & $\mathrm{R}-83498$ & 4 & 55.495 & 36.039 & S-20 & 7 & Moskovskaya oblast', Mozhajskij rajon & Moscow region, Mozhaisky district \\
\hline 33 & $\mathrm{R}-83500$ & 4 & 55.495 & 36.039 & S-20 & 7 & Moskovskaya oblast', Mozhajskij rajon & Moscow region, Mozhaisky district \\
\hline 34 & $R-83495$ & 6 & 55.495 & 36.039 & $\mathrm{~S}-20$ & 7 & Moskovskaya oblast', Mozhajskij rajon & Moscow region, Mozhaisky district \\
\hline 35 & $\mathrm{R}-83496$ & 7 & 55.495 & 36.039 & $\mathrm{~S}-20$ & 7 & Moskovskaya oblast', Mozhajskij rajon & Moscow region, Mozhaisky district \\
\hline 36 & R-83499 & 5 & 55.495 & 36.039 & $\mathrm{~S}-20$ & 7 & Moskovskaya oblast', Mozhajskij rajon & Moscow region, Mozhaisky district \\
\hline
\end{tabular}




\begin{tabular}{|c|c|c|c|c|c|c|c|c|}
\hline 37 & R-117088 & 5 & 55.536 & 37.066 & S-20 & 7 & $\begin{array}{l}\text { Moskovskaya oblast', Narofominskij rajon, } \\
\text { Aprelevka }\end{array}$ & $\begin{array}{l}\text { Moscow region, Narofominsky district, } \\
\text { Aprelevka }\end{array}$ \\
\hline 38 & R-117092 & 4 & 55.536 & 37.066 & S-20 & 7 & $\begin{array}{l}\text { Moskovskaya oblast', Narofominskij rajon, } \\
\text { Aprelevka }\end{array}$ & $\begin{array}{l}\text { Moscow region, Narofominsky district, } \\
\text { Aprelevka }\end{array}$ \\
\hline 39 & R-60216 & 5 & 55.861 & 38.783 & $\mathrm{~S}-22$ & 7 & Moskovskaya oblast', Noginskij rajon & Moscow region, Noginsk district \\
\hline 40 & R-60234 & 4 & 55.861 & 38.783 & $\mathrm{~S}-22$ & 7 & Moskovskaya oblast', Noginskij rajon & Moscow region, Noginsk district \\
\hline 41 & R-60212 & 6 & 55.861 & 38.783 & $\mathrm{~S}-22$ & 7 & Moskovskaya oblast', Noginskij rajon & Moscow region, Noginsk district \\
\hline 42 & R-? & 6 & 55.861 & 38.783 & $\mathrm{~S}-22$ & 7 & Moskovskaya oblast', Noginskij rajon & Moscow region, Noginsk district \\
\hline 43 & R-60226 & 4 & 55.861 & 38.783 & $\mathrm{~S}-22$ & 7 & Moskovskaya oblast', Noginskij rajon & Moscow region, Noginsk district \\
\hline 44 & R-60218 & 5 & 55.861 & 38.783 & $\mathrm{~S}-22$ & 7 & Moskovskaya oblast', Noginskij rajon & Moscow region, Noginsk district \\
\hline 45 & R-60235 & 7 & 55.861 & 38.783 & $\mathrm{~S}-22$ & 7 & Moskovskaya oblast', Noginskij rajon & Moscow region, Noginsk district \\
\hline 46 & R-60239 & 5 & 55.861 & 38.783 & $\mathrm{~S}-22$ & 7 & Moskovskaya oblast', Noginskij rajon & Moscow region, Noginsk district \\
\hline 47 & R-60232 & 6 & 55.861 & 38.783 & $\mathrm{~S}-22$ & 7 & Moskovskaya oblast', Noginskij rajon & Moscow region, Noginsk district \\
\hline 48 & R-60227 & 3 & 55.861 & 38.783 & S-22 & 7 & Moskovskaya oblast', Noginskij rajon & Moscow region, Noginsk district \\
\hline 49 & R-60221 & 3 & 55.861 & 38.783 & $\mathrm{~S}-22$ & 7 & Moskovskaya oblast', Noginskij rajon & Moscow region, Noginsk district \\
\hline 50 & R-60217 & 3 & 55.861 & 38.783 & $\mathrm{~S}-22$ & 7 & Moskovskaya oblast', Noginskij rajon & Moscow region, Noginsk district \\
\hline 51 & R-60229 & 5 & 55.861 & 38.783 & $\mathrm{~S}-22$ & 7 & Moskovskaya oblast', Noginskij rajon & Moscow region, Noginsk district \\
\hline 52 & R-60233 & 4 & 55.861 & 38.783 & $\mathrm{~S}-22$ & 7 & Moskovskaya oblast', Noginskij rajon & Moscow region, Noginsk district \\
\hline 53 & R-60238 & 4 & 55.861 & 38.783 & $\mathrm{~S}-22$ & 7 & Moskovskaya oblast', Noginskij rajon & Moscow region, Noginsk district \\
\hline 54 & R-60213 & 4 & 55.861 & 38.783 & S-22 & 7 & Moskovskaya oblast', Noginskij rajon & Moscow region, Noginsk district \\
\hline 55 & R-60236 & 3 & 55.861 & 38.783 & $\mathrm{~S}-22$ & 7 & Moskovskaya oblast', Noginskij rajon & Moscow region, Noginsk district \\
\hline 56 & R-60219 & 2 & 55.861 & 38.783 & $\mathrm{~S}-22$ & 7 & Moskovskaya oblast', Noginskij rajon & Moscow region, Noginsk district \\
\hline 57 & R-60211 & 4 & 55.861 & 38.783 & $\mathrm{~S}-22$ & 7 & Moskovskaya oblast', Noginskij rajon & Moscow region, Noginsk district \\
\hline 58 & R-60222 & 7 & 55.861 & 38.783 & $\mathrm{~S}-22$ & 7 & Moskovskaya oblast', Noginskij rajon & Moscow region, Noginsk district \\
\hline 59 & R-68209 & 2 & 55.861 & 38.783 & $\mathrm{~S}-22$ & 7 & Moskovskaya oblast', Noginskij rajon & Moscow region, Noginsk district \\
\hline 60 & R-60224 & 3 & 55.861 & 38.783 & S-22 & 7 & Moskovskaya oblast', Noginskij rajon & Moscow region, Noginsk district \\
\hline 61 & R-11736 & 3 & 55.438 & 37.565 & $\mathrm{~S}-22$ & 7 & Moskovskaya oblast', Podol'skij rajon & Moscow region, Podolsky district \\
\hline 62 & R-11726 & 6 & 55.438 & 37.565 & $\mathrm{~S}-22$ & 7 & Moskovskaya oblast', Podol'skij rajon & Moscow region, Podolsky district \\
\hline 63 & R-11734 & 4 & 55.438 & 37.565 & $\mathrm{~S}-22$ & 7 & Moskovskaya oblast', Podol'skij rajon & Moscow region, Podolsky district \\
\hline 64 & R-11725 & 4 & 55.438 & 37.565 & $\mathrm{~S}-22$ & 7 & Moskovskaya oblast', Podol'skij rajon & Moscow region, Podolsky district \\
\hline 65 & R-109820 & 7 & 55.503 & 37.305 & $\mathrm{~S}-20$ & 7 & Moskovskaya oblast', reka Desna & Moscow region, Desna river \\
\hline 66 & $\mathrm{R}-109817$ & 4 & 55.503 & 37.305 & $S-20$ & 7 & Moskovskaya oblast', reka Desna & Moscow region, Desna river \\
\hline 67 & $\mathrm{R}-109819$ & 6 & 55.772 & 37.432 & S-20 & 7 & Moskovskaya oblast', Serebryanyj bor & Moscow region, Serebryanny Bor \\
\hline 68 & $\mathrm{R}-117096$ & 5 & 54.889 & 38.114 & $\mathrm{~S}-21$ & 7 & Moskovskaya oblast', Stupinskij rajon & Moscow region, Stupinsky district \\
\hline 69 & $\mathrm{R}-117095$ & 6 & 54.889 & 38.114 & $\mathrm{~S}-21$ & 7 & Moskovskaya oblast', Stupinskij rajon & Moscow region, Stupinsky district \\
\hline 70 & R-11733 & 4 & 57.421 & 27.055 & $\mathrm{~S}-6$ & 7 & Marienburg, Liflyandiya & Marienburg, Livonia \\
\hline 71 & R-11731 & 2 & 57.421 & 27.055 & S-6 & 7 & Marienburg, Liflyandiya & Marienburg, Livonia \\
\hline 72 & R-11727 & 6 & 57.421 & 27.055 & $\mathrm{~S}-6$ & 7 & Marienburg, Liflyandiya & Marienburg, Livonia \\
\hline 73 & R-11751 & 4 & 57.421 & 27.055 & S-6 & 7 & Marienburg, Liflyandiya & Marienburg, Livonia \\
\hline 74 & R-93065 & 4 & 53.901 & 27.557 & S-9 & 7 & Minskaya oblast'ast' & Minsk region \\
\hline 75 & R-60241 & 4 & 55.752 & 37.614 & $\mathrm{~S}-22$ & 7 & Moskva & Moscow \\
\hline 76 & R-60207 & 4 & 55.752 & 37.614 & $\mathrm{~S}-22$ & 7 & Moskva & Moscow \\
\hline 77 & R-60242 & 4 & 55.752 & 37.614 & $\mathrm{~S}-22$ & 7 & Moskva & Moscow \\
\hline 78 & R-11739 & 6 & 55.752 & 37.614 & $\mathrm{~S}-22$ & 7 & Moskva & Moscow \\
\hline
\end{tabular}




\begin{tabular}{|c|c|c|c|c|c|c|c|c|}
\hline 79 & R-116590 & 7 & 55.752 & 37.614 & $S-22$ & 7 & Moskva & Moscow \\
\hline 80 & R-117087 & 4 & 55.752 & 37.614 & $\mathrm{~S}-22$ & 7 & Moskva & Moscow \\
\hline 81 & R-60260 & 3 & 56.741 & 38.852 & $\mathrm{~S}-22$ & 7 & Pereslavl'-Zalesskij & Pereslavl-Zalessky \\
\hline 82 & R-60261 & 7 & 56.741 & 38.852 & $\mathrm{~S}-22$ & 7 & Pereslavl'-Zalesskij & Pereslavl-Zalessky \\
\hline 83 & R-60204 & 4 & 56.741 & 38.852 & $\mathrm{~S}-22$ & 7 & Pereslavskij rajon & Pereslavsky district \\
\hline 84 & R-60259 & 2 & 56.741 & 38.852 & $S-22$ & 7 & Pereslavskij rajon & Pereslavsky district \\
\hline 85 & R-60205 & 5 & 56.741 & 38.852 & $S-22$ & 7 & Pereslavskij rajon & Pereslavsky district \\
\hline 86 & R-60273 & 3 & 61.838 & 56.864 & $L-6$ & 7 & Pechorskij zapovednik (poselok Ilychskij?) & Pechora Nature Reserve (Ilychsky village?) \\
\hline 87 & R-50636 & 4 & 61.838 & 56.864 & $\mathrm{~L}-6$ & 7 & Pechora, dolina reki UI'n & Pechora, Uln River Valley \\
\hline 88 & R-35771 & 3 & 55.174 & 59.654 & $\mathrm{~L}-6$ & 7 & reka Malyj Syrostan, u Zlatousta & Maly Syrostan river, near Chrysostom \\
\hline 89 & R-65543 & 4 & 54.834 & 40.915 & $\mathrm{~S}-23$ & 7 & $\begin{array}{l}\text { Ryazanskaya oblast', Bel'kovskij rajon, selo } \\
\text { Aluhtinskie dvoriki }\end{array}$ & $\begin{array}{l}\text { Ryazan region, Belkovsky district, village } \\
\text { Alukhtinsky courtyards }\end{array}$ \\
\hline 90 & R-60262 & 3 & 54.541 & 40.859 & S-23 & 7 & Ryazanskaya oblast', Izhevskij rajon & Ryazan region, Izhevsky district \\
\hline 91 & R-11741 & 3 & 54.236 & 39.011 & $\mathrm{~S}-21$ & 7 & Ryazanskaya oblast'ast'. Mihalovskij rajon & Ryazan region Michalovsky district \\
\hline 92 & R-29254 & 7 & 54.231 & 85.803 & S-31 & 7 & Salair, verhov'ya reki CHulysh & Salair, the upper reaches of the river Chulysh \\
\hline 93 & R-29255 & 7 & 54.231 & 85.803 & $\mathrm{~S}-31$ & 7 & Salair, verhov'ya reki CHulysh & Salair, the upper reaches of the river Chulysh \\
\hline 94 & R-29247 & 4 & 54.231 & 85.803 & $\mathrm{~S}-31$ & 7 & Salair, reka Syuhta & Salair, Syukhta River \\
\hline 95 & R-29256 & 6 & 54.231 & 85.803 & $\mathrm{~S}-31$ & 7 & Salair, reka Syuhta & Salair, Syukhta River \\
\hline 96 & R-29245 & 4 & 56.508 & 84.973 & $L-8$ & 7 & Tomsk & Tomsk \\
\hline 97 & R-29246 & 5 & 56.508 & 84.973 & $\mathrm{~L}-8$ & 7 & Tomsk & Tomsk \\
\hline 98 & R-29252 & 6 & 57.167 & 65.501 & $\mathrm{~S}-30$ & 7 & Tyumen' & Tyumen \\
\hline 99 & R-30168 & 4 & 57.167 & 65.501 & $\mathrm{~S}-30$ & 7 & Tyumen' & Tyumen \\
\hline 100 & R-29251 & 7 & 57.167 & 65.501 & $\mathrm{~S}-30$ & 7 & Tyumen' & Tyumen \\
\hline 101 & R-93314 & 5 & 63.934 & 66.161 & L-7 & 7 & $\begin{array}{l}\text { Hantymansijskij nacional'nyj okrug, Nizhnyaya } \\
\text { Ob' }\end{array}$ & Khanty-Mansi National District, Lower Ob \\
\hline 102 & R-70519 & 4 & 56.531 & 32.861 & S-17 & 7 & Central'nyj lesnoj gosudarstvennyj zapovednik & Central Forest State Reserve \\
\hline 103 & R-70517 & 2 & 56.531 & 32.861 & $\mathrm{~S}-17$ & 7 & Central'nyj lesnoj gosudarstvennyj zapovednik & Central Forest State Reserve \\
\hline 104 & 21358 & 7 & 49.132 & 46.819 & $\mathrm{~L}-2$ & 3 & EHI'ton & Elton \\
\hline 105 & R-15996 & 6 & 52.297 & 56.997 & $\mathrm{~S}-29$ & 7 & YUzhnyj Ural & Southern Urals \\
\hline 106 & R-35772 & 3 & 52.297 & 56.997 & S-29 & 7 & YUzhnyj Ural, Aleksandrovka & South Ural, Aleksandrovka \\
\hline 107 & $R-109146$ & 4 & 52.001 & 57.034 & S-29 & 7 & YUzhnyj Ural, verhov'ya reki Kasmarka & South Ural, headwaters of the Kasmark \\
\hline 108 & R-15994 & 4 & 51.551 & 56.915 & S-29 & 7 & YUzhnyj Ural, Ziyanchurinskij rajon & South Ural, Zianchurinsky District \\
\hline 109 & R-15993 & 6 & 51.551 & 56.915 & S-29 & 7 & YUzhnyj Ural, Ziyanchurinskij rajon & South Ural, Zianchurinsky District \\
\hline 110 & R-35773 & 7 & 55.166 & 60.118 & $L-6$ & 7 & YUzhnyj Ural, Turgoyak & South Ural, Turgoyak \\
\hline 111 & R-48062 & 4 & 57.607 & 39.858 & $\mathrm{~S}-22$ & 7 & YAroslavskaya oblast' & Yaroslavskaya oblast \\
\hline 112 & R-60271 & 4 & 57.607 & 39.858 & $\mathrm{~S}-22$ & 7 & YAroslavskaya oblast' & Yaroslavskaya oblast \\
\hline 113 & R-60256 & 6 & 57.607 & 39.858 & $\mathrm{~S}-22$ & 7 & YAroslavskaya oblast' & Yaroslavskaya oblast \\
\hline 114 & R-60206 & 7 & 56.769 & 38.761 & $\mathrm{~S}-22$ & 7 & YAroslavskaya oblast', Pleshcheevo & Yaroslavl region, Plescheevo \\
\hline 115 & 1462.188 & 4 & 54.533 & 28.531 & S-9 & 6 & Belorussiya, Minskaya oblast'ast', Kletnoe & Belarus, Minsk region, Kletnoe \\
\hline 116 & $1455 / 639$ & 6 & 53.834 & 30.233 & $\mathrm{~S}-13$ & 6 & Belorussiya, Mogilyovsk, Selec & Belarus, Mogilevsk, Selets \\
\hline 117 & $1452 / 1775$ & 6 & 53.442 & 31.005 & $\mathrm{~S}-13$ & 6 & Belorussiya, Propojsk, CHizhenka & Belarus, Propoisk, Chizhenka \\
\hline 118 & $1454 \backslash 815$ & 6 & 55.355 & 29.299 & S-9 & 6 & Belorussiya, Vitebskaya oblast'ast' Obol' & Belarus, Vitebsk region Obol \\
\hline 119 & $1456 \backslash 532$ & 7 & 53.834 & 30.233 & $\mathrm{~S}-13$ & 6 & Belorussiya, Mogilyovsk, YUr'evo & Belarus, Mogilevsk, Yuryevo \\
\hline 120 & N/A & 4 & 53.834 & 30.233 & $\mathrm{~S}-13$ & 6 & Belorussiya, Mogilyovsk, YUr'evo & Belarus, Mogilevsk, Yuryevo \\
\hline
\end{tabular}




\begin{tabular}{|c|c|c|c|c|c|c|c|c|}
\hline 121 & $1458 \backslash 601$ & 6 & 53.834 & 30.233 & $\mathrm{~S}-13$ & 6 & Belorussiya, Mogilyovsk, & Belarus, Mogilevsk, \\
\hline 122 & $1463 \backslash 35$ & 4 & 53.417 & 27.918 & S-9 & 6 & $\begin{array}{l}\text { Belorussiya, Minskaya oblast'ast', Igumenskij } \\
\text { rajon, Gorelec }\end{array}$ & Belarus, Minsk region, Igumen district, Gorelets \\
\hline 123 & $1457 \backslash 458$ & 7 & 53.701 & 28.249 & S-9 & 6 & $\begin{array}{l}\text { Belorussiya, Minskaya oblast'ast', Igumenskij } \\
\text { rajon }\end{array}$ & Belarus, Minsk region, Igumen district \\
\hline 124 & $1472 \backslash 731$ & 4 & 54.889 & 28.698 & S-9 & 6 & Belorussiya, Lepel'skij rajon & Belarus, Lepel district \\
\hline 125 & 1385 & 5 & 54.502 & 30.405 & $S-13$ & 6 & Vitebskaya oblast', Orshanskij rajon & Vitebsk region, Orsha district \\
\hline 126 & 1391 & 2 & 53.901 & 27.557 & S-9 & 6 & Minskaya oblast'ast', Belopol'sk rajon & Minsk region, Belopolsk district \\
\hline 127 & $\mathrm{~N} / \mathrm{A}$ & 7 & 50.351 & 46.416 & $\mathrm{~L}-2$ & 9 & Volgogradskaya oblast'ast', Valuevka & Volgograd region, Valuevka \\
\hline 128 & 1380 & 5 & 54.502 & 30.405 & $\mathrm{~S}-13$ & 6 & Vitebskaya oblast', Orshanskij rajon & Vitebsk region, Orsha district \\
\hline 129 & $\mathrm{~N} / \mathrm{A}$ & 5 & 54.502 & 30.405 & $S-13$ & 6 & Vitebskaya oblast', Orshanskij rajon & Vitebsk region, Orsha district \\
\hline 130 & A5748 & 4 & 56.163 & 91.389 & $\mathrm{~L}-8$ & 2 & Krasnoyarskij kraj, Kozul'skij rajon & Krasnoyarsk Territory, Kozulsky District \\
\hline 131 & A5745 & 6 & 54.697 & 40.849 & $\mathrm{~S}-23$ & 2 & Okskij zapovednikk & Oksky Reserve \\
\hline 132 & A5746 & 5 & 54.697 & 40.849 & S-23 & 2 & Okskij zapovednikk & Oksky Reserve \\
\hline 133 & A5747 & 3 & 54.697 & 40.849 & $\mathrm{~S}-23$ & 2 & Okskij zapovednikk & Oksky Reserve \\
\hline 134 & $\mathrm{~N} / \mathrm{A}$ & 4 & 55.162 & 20.837 & $\mathrm{~S}-2$ & 9 & Kurshskaya kosa & Curonian Spit \\
\hline 135 & $\mathrm{~N} / \mathrm{A}$ & 5 & 55.162 & 20.837 & $\mathrm{~S}-2$ & 9 & Kurshskaya kosa & Curonian Spit \\
\hline 136 & $\mathrm{~N} / \mathrm{A}$ & 4 & 55.162 & 20.837 & $\mathrm{~S}-2$ & 9 & Kurshskaya kosa & Curonian Spit \\
\hline 137 & $\mathrm{~N} / \mathrm{A}$ & 5 & 55.162 & 20.837 & $\mathrm{~S}-2$ & 9 & Kurshskaya kosa & Curonian Spit \\
\hline 138 & $\mathrm{~N} / \mathrm{A}$ & 2 & 62.917 & 34.455 & $L-4$ & 9 & Kareliya, Medvezh'ya gora & Karelia, Bear Mountain \\
\hline 139 & $\mathrm{~N} / \mathrm{A}$ & 6 & 55.162 & 20.837 & $\mathrm{~S}-2$ & 9 & Kurshskaya kosa & Curonian Spit \\
\hline 140 & $\mathrm{~N} / \mathrm{A}$ & 5 & 55.162 & 20.837 & $\mathrm{~S}-2$ & 9 & Kurshskaya kosa & Curonian Spit \\
\hline 141 & $\mathrm{~N} / \mathrm{A}$ & 3 & 55.162 & 20.837 & $\mathrm{~S}-2$ & 9 & Kurshskaya kosa & Curonian Spit \\
\hline 142 & $\mathrm{~N} / \mathrm{A}$ & 4 & 55.162 & 20.837 & $\mathrm{~S}-2$ & 9 & Kurshskaya kosa & Curonian Spit \\
\hline 143 & $\mathrm{~N} / \mathrm{A}$ & 5 & 55.162 & 20.837 & $\mathrm{~S}-2$ & 9 & Kurshskaya kosa & Curonian Spit \\
\hline 144 & $\mathrm{~N} / \mathrm{A}$ & 2 & 55.162 & 20.837 & $\mathrm{~S}-2$ & 9 & Kurshskaya kosa & Curonian Spit \\
\hline 145 & $\mathrm{~N} / \mathrm{A}$ & 4 & 55.162 & 20.837 & $\mathrm{~S}-2$ & 9 & Kurshskaya kosa & Curonian Spit \\
\hline 146 & $\mathrm{~N} / \mathrm{A}$ & 4 & 59.717 & 29.464 & $\mathrm{~S}-10$ & 9 & Leningradskaya oblast'ast', Novaya burya & Leningrad region, New Storm \\
\hline 147 & $\mathrm{~N} / \mathrm{A}$ & 3 & 59.934 & 30.319 & $\mathrm{~S}-14$ & 9 & Sankt-Peterburg & St. Petersburg \\
\hline 148 & $\mathrm{~N} / \mathrm{A}$ & 3 & 59.934 & 30.319 & $\mathrm{~S}-14$ & 9 & Sankt-Peterburg & St. Petersburg \\
\hline 149 & $\mathrm{~N} / \mathrm{A}$ & 4 & 59.717 & 29.464 & $\mathrm{~S}-10$ & 9 & Leningradskaya oblast'ast', Novaya burya & Leningrad region, New Storm \\
\hline 150 & $\mathrm{~N} / \mathrm{A}$ & 4 & 59.717 & 29.464 & $\mathrm{~S}-10$ & 9 & Leningradskaya oblast'ast', Novaya burya & Leningrad region, New Storm \\
\hline 151 & $\mathrm{~N} / \mathrm{A}$ & 2 & 59.717 & 29.464 & S-10 & 9 & Leningradskaya oblast'ast', Novaya burya & Leningrad region, New Storm \\
\hline 152 & $\mathrm{~N} / \mathrm{A}$ & 4 & 59.717 & 29.464 & $\mathrm{~S}-10$ & 9 & Leningradskaya oblast'ast', Novaya burya & Leningrad region, New Storm \\
\hline 153 & $\mathrm{~N} / \mathrm{A}$ & 5 & 59.934 & 30.319 & $\mathrm{~S}-14$ & 9 & Sankt-Peterburg & St. Petersburg \\
\hline 154 & $\mathrm{~N} / \mathrm{A}$ & 4 & 57.667 & 41.031 & S-24 & 9 & Kostromskaya oblast', YUr'eveckij rajon & Kostroma region, Yuryevets district \\
\hline 155 & $\mathrm{~N} / \mathrm{A}$ & 4 & 57.452 & 42.125 & S-24 & 9 & Ivanovskaya oblast'ast', Kineshnyj rajon & Ivanovo region, Kineshny district \\
\hline 156 & $\mathrm{~N} / \mathrm{A}$ & 4 & 67.591 & 32.833 & $\mathrm{~L}-3$ & 9 & Kol'skij poluostrov, ozero Imandra & Kola Peninsula, Imandra Lake \\
\hline 157 & $\mathrm{~N} / \mathrm{A}$ & 3 & 61.686 & 33.614 & $\mathrm{~L}-4$ & 9 & Kareliya, Pryazhinskij rajon & Karelia, Pryazha district \\
\hline 158 & $\mathrm{~N} / \mathrm{A}$ & 4 & 59.934 & 30.319 & $\mathrm{~S}-14$ & 9 & Sankt-Peterburg & St. Petersburg \\
\hline 159 & $\mathrm{~N} / \mathrm{A}$ & 2 & 61.686 & 33.614 & $\mathrm{~L}-4$ & 9 & Kareliya, Pryazhinskij rajon & Karelia, Pryazha district \\
\hline 160 & $\mathrm{~N} / \mathrm{A}$ & 2 & 61.686 & 33.614 & $\mathrm{~L}-4$ & 9 & Kareliya, Pryazhinskij rajon & Karelia, Pryazha district \\
\hline 161 & $\mathrm{~N} / \mathrm{A}$ & 5 & 55.752 & 37.614 & $\mathrm{~S}-22$ & 9 & Moskva & Moscow \\
\hline 162 & $\mathrm{~N} / \mathrm{A}$ & 4 & 55.752 & 37.614 & $\mathrm{~S}-22$ & 9 & Moskva & Moscow \\
\hline
\end{tabular}




\begin{tabular}{|c|c|c|c|c|c|c|c|c|}
\hline $163 \mid$ & $\mathrm{N} / \mathrm{A}$ & 4 & 57.819 & 58.843 & $\mathrm{~L}-6$ & 9 & Permskaya oblast'ast', reka Serebryanka & Perm Region, Serebryanka River \\
\hline $164 \mid$ & $\mathrm{N} / \mathrm{A}$ & 4 & 59.151 & 30.833 & S-14 & 9 & Leningradskaya oblast'ast', Dubovik & Leningrad region, Dubovik \\
\hline 165 & $\mathrm{~N} / \mathrm{A}$ & 5 & 57.452 & 42.125 & S-24 & 9 & Ivanovskaya oblast'ast', Kineshnyj rajon & Ivanovo region, Kineshny district \\
\hline 166 & $\mathrm{~N} / \mathrm{A}$ & 6 & 54.933 & 41.401 & S-23 & 9 & Ryazanskaya oblast'ast', Kasimovskij rajon & Ryazan region, Kasimov district \\
\hline $167 \mid$ & N/A & 3 & 59.756 & 31.072 & S-14 & 9 & Leningradskaya oblast'ast', Mihajlovskij rajon & Leningrad region, Mikhailovsky district \\
\hline 168 & N/A & 6 & 58.017 & 30.283 & S-14 & 9 & Novgorodskaya, oblast', Velesh & Novgorod region, Veles \\
\hline 169 & N/A & 2 & 67.976 & 39.831 & $\mathrm{~L}-3$ & 9 & Murmanskaya oblast', lokanga & Murmansk region, lokanga \\
\hline 170 & A5743 & 5 & 56.317 & 44.001 & S-25 & 2 & Nizhnij Novgorod & Nizhny Novgorod \\
\hline $171 /$ & A5741 & 3 & 56.317 & 44.001 & S-25 & 2 & Nizhnij Novgorod & Nizhny Novgorod \\
\hline 172 & A5742 & 6 & 56.317 & 44.001 & S-25 & 2 & Nizhnij Novgorod & Nizhny Novgorod \\
\hline 173 & $\mathrm{~N} / \mathrm{A}$ & 5 & 56.317 & 44.001 & S-25 & 9 & Nizhnij Novgorod & Nizhny Novgorod \\
\hline 174 & $\mathrm{~N} / \mathrm{A}$ & 3 & 56.317 & 44.001 & S-25 & 9 & Nizhnij Novgorod & Nizhny Novgorod \\
\hline 175 & $\mathrm{~N} / \mathrm{A}$ & 6 & 57.997 & 31.361 & S-14 & 9 & Novgorskaya oblast', Starorussk rajon & Novgorod region, Starorussky district \\
\hline 176 & $\mathrm{~N} / \mathrm{A}$ & 7 & 57.819 & 58.843 & $\mathrm{~L}-6$ & 9 & Permskaya oblast'ast', reka Serebryanka & Perm Region, Serebryanka River \\
\hline 177 & $\mathrm{~N} / \mathrm{A}$ & 6 & 56.682 & 34.715 & S-17 & 9 & Tverskaya oblast', Bernovo & Tver region, Bernovo \\
\hline 178 & $\mathrm{~N} / \mathrm{A}$ & 6 & 57.436 & 56.942 & $\mathrm{~L}-6$ & 9 & permsk. oblast'ast' kungur & Perm. area kungur \\
\hline 179 & N/A & 7 & 51.782 & 55.107 & S-29 & 9 & Orenburg & Orenburg \\
\hline $180 \mid$ & $\mathrm{N} / \mathrm{A}$ & 6 & 54.975 & 73.382 & $\mathrm{~N} / \mathrm{A}$ & 9 & Omsk & Omsk \\
\hline 181 & $\mathrm{~N} / \mathrm{A}$ & 7 & 58.187 & 68.243 & $\mathrm{~L}-7$ & 9 & Tobol'sk & Tobolsk \\
\hline $182 \mid$ & $\mathrm{N} / \mathrm{A}$ & 7 & 55.051 & 59.922 & $\mathrm{~L}-6$ & 9 & YUzhnyj ural, Syrostan & South Ural, Syrostan \\
\hline $183 \mid$ & N/A & 5 & 56.508 & 84.973 & $\mathrm{~L}-8$ & 9 & Tomsk & Tomsk \\
\hline $184 \mid$ & N/A & 5 & 53.651 & 52.448 & $\mathrm{~S}-27$ & 9 & Orenburgskaya oblast', Buguruslan & Orenburg region, Buguruslan \\
\hline 185 & $\mathrm{~N} / \mathrm{A}$ & 6 & 51.782 & 55.107 & S-29 & 9 & Orenburg & Orenburg \\
\hline 186 & $\mathrm{~N} / \mathrm{A}$ & 6 & 63.933 & 65.042 & $\mathrm{~L}-7$ & 9 & Beryozov (Komi) & Berezov (Komi) \\
\hline $187 \mid$ & $\mathrm{N} / \mathrm{A}$ & 6 & 58.283 & 31.315 & S-14 & 9 & |ll'men' & IImen \\
\hline 188 & N/A & 6 & 56.508 & 84.973 & $\mathrm{~L}-8$ & 9 & Tomsk & Tomsk \\
\hline 189 & $\mathrm{~N} / \mathrm{A}$ & 7 & 53.651 & 52.448 & S-27 & 9 & Orenburgskaya oblast', Buguruslan & Orenburg region, Buguruslan \\
\hline 190 & $\mathrm{~N} / \mathrm{A}$ & 5 & 57.167 & 65.501 & S-30 & 9 & Tyumen' & Tyumen \\
\hline 191 & $\mathrm{~N} / \mathrm{A}$ & 5 & 53.651 & 52.448 & S-27 & 9 & Orenburgskaya oblast', Buguruslan & Orenburg region, Buguruslan \\
\hline 192 & N/A & 4 & 53.651 & 52.448 & $\mathrm{~S}-27$ & 9 & Orenburgskaya oblast', Buguruslan & Orenburg region, Buguruslan \\
\hline $193 \mid$ & $\mathrm{N} / \mathrm{A}$ & 4 & 53.651 & 52.448 & S-27 & 9 & Orenburgskaya oblast', Buguruslan & Orenburg region, Buguruslan \\
\hline $194 \mid$ & $\mathrm{N} / \mathrm{A}$ & 3 & 56.025 & 93.061 & $\mathrm{~L}-8$ & 9 & Krasnoyarsk & Krasnoyarsk \\
\hline 195 & $\mathrm{~N} / \mathrm{A}$ & 3 & 57.167 & 65.501 & S-30 & 9 & |Tyumenskaya, Oblast'ast' & Tyumen region \\
\hline $196 \mid$ & $\mathrm{N} / \mathrm{A}$ & 4 & 58.187 & 68.243 & $\mathrm{~L}-7$ & 9 & Tobol'sk & Tobolsk \\
\hline $197 \mid$ & $\mathrm{N} / \mathrm{A}$ & 4 & 58.187 & 68.243 & $\mathrm{~L}-7$ & 9 & Tobol'sk & Tobolsk \\
\hline 198 & $\mathrm{~N} / \mathrm{A}$ & 4 & 58.283 & 31.315 & S-14 & 9 & |II'men' & IImen \\
\hline 199 & $\mathrm{~N} / \mathrm{A}$ & 4 & 58.283 & 31.315 & S-14 & 9 & |II'men' & IIImen \\
\hline 200 & N/A & 3 & 56.183 & 51.332 & $\mathrm{~S}-28$ & 10 & Kirovskaya oblast'ast', Ust'-Lyusa & Kirov region, Ust-Luce \\
\hline 2011 & $\mathrm{~N} / \mathrm{A}$ & 5 & 59.848 & 48.284 & $\mathrm{~L}-5$ & 10 & Kirovskaya oblast'ast', Oparinskij rajon & Kirov region, Oparinsky district \\
\hline $202 \mid$ & $\mathrm{N} / \mathrm{A}$ & 6 & 56.366 & 50.998 & $\mathrm{~S}-28$ & 10 & Kirovskaya oblast', Karakul'naya pristan' & Kirov region, Karakulnaya pier \\
\hline $203 \mid$ & $\mathrm{N} / \mathrm{A}$ & 2 & 56.366 & 50.998 & S-28 & 10 & Kirovskaya oblast', Karakul'naya pristan' & Kirov region, Karakulnaya pier \\
\hline $204 \mid$ & $\mathrm{N} / \mathrm{A}$ & 3 & 58.832 & 47.884 & $\mathrm{~L}-5$ & 10 & Kirovskaya oblast'ast', Bobrovy & Kirov region, Bobrov \\
\hline 205 & $\mathrm{~N} / \mathrm{A}$ & 5 & 59.848 & 48.284 & $\mathrm{~L}-5$ & 10 & Kirovskaya oblast'ast', Oparinskij rajon & Kirov region, Oparinsky district \\
\hline 206 & $\mathrm{~N} / \mathrm{A}$ & 4 & 56.183 & 51.332 & S-28 & 10 & Kirovskaya oblast'ast', Ust'-Lyusa & Kirov region, Ust-Luce \\
\hline
\end{tabular}




\begin{tabular}{|c|c|c|c|c|c|c|c|c|}
\hline 207 & $\mathrm{~N} / \mathrm{A}$ & 3 & 59.848 & 48.284 & $L-5$ & 10 & Kirovskaya oblast'ast', Oparinskij rajon & Kirov region, Oparinsky district \\
\hline 208 & $\mathrm{~N} / \mathrm{A}$ & 5 & 56.183 & 51.332 & S-28 & 10 & Kirovskaya oblast'ast', Ust'-Lyusa & Kirov region, Ust-Luce \\
\hline 209 & $\mathrm{~N} / \mathrm{A}$ & 6 & 56.848 & 50.181 & S-28 & 10 & Kirovskaya oblast'ast', Lazorevo & Kirov region, Azorevo \\
\hline 210 & $\mathrm{~N} / \mathrm{A}$ & 7 & 56.183 & 51.332 & S-28 & 10 & Kirovskaya oblast'ast', Ust'-Lyusa & Kirov region, Ust-Luce \\
\hline 211 & $\mathrm{~N} / \mathrm{A}$ & 3 & 59.332 & 52.245 & $L-5$ & 10 & Kirovskaya oblast'ast', lerhnekamskij rajon & Kirov region, lerhnekamsk district \\
\hline 212 & $\mathrm{~N} / \mathrm{A}$ & 2 & 56.366 & 50.998 & S-28 & 10 & Kirovskaya oblast', Karakul'naya pristan' & Kirov region, Karakulnaya pier \\
\hline 213 & $\mathrm{~N} / \mathrm{A}$ & 3 & 56.366 & 50.998 & S-28 & 10 & Kirovskaya oblast', Karakul'naya pristan' & Kirov region, Karakulnaya pier \\
\hline 214 & $\mathrm{~N} / \mathrm{A}$ & 4 & 57.491 & 48.582 & S-28 & 10 & Kirovskaya oblast'ast', Pizhanskij rajon & Kirov region, Pizhansky district \\
\hline 215 & $\mathrm{~N} / \mathrm{A}$ & 2 & 56.183 & 51.332 & S-28 & 10 & Kirovskaya oblast'ast', Ust'-Lyusa & Kirov region, Ust-Luce \\
\hline 216 & $\mathrm{~N} / \mathrm{A}$ & 4 & 56.183 & 51.332 & S-28 & 10 & Kirovskaya oblast'ast', Ust'-Lyusa & Kirov region, Ust-Luce \\
\hline 217 & $\mathrm{~N} / \mathrm{A}$ & 6 & 55.002 & 23.838 & $\mathrm{~S}-4$ & 11 & Kauno, Litva & Kauno, Litva \\
\hline 218 & $\mathrm{~N} / \mathrm{A}$ & 4 & 54.928 & 23.699 & S-4 & 11 & Kacergine, Litva & Kacergine, Litva \\
\hline 219 & $\mathrm{~N} / \mathrm{A}$ & 4 & 54.966 & 24.167 & $\mathrm{~S}-4$ & 11 & Didysis raistas, Litva & Didysis raistas, Litva \\
\hline 220 & $\mathrm{~N} / \mathrm{A}$ & 4 & 55.002 & 23.838 & $\mathrm{~S}-4$ & 11 & Kauno, Litva & Kauno, Litva \\
\hline 221 & $\mathrm{~N} / \mathrm{A}$ & 4 & 54.219 & 24.564 & $\mathrm{~S}-4$ & 11 & Varena, Litva & Varena, Litva \\
\hline 222 & $\mathrm{~N} / \mathrm{A}$ & 4 & 54.219 & 24.564 & $\mathrm{~S}-4$ & 11 & Varena, Litva & Varena, Litva \\
\hline 223 & $\mathrm{~N} / \mathrm{A}$ & 4 & 56.051 & 21.813 & $\mathrm{~S}-2$ & 11 & Plunges, Platelis & Plunges, Platelis \\
\hline 224 & $\mathrm{~N} / \mathrm{A}$ & 3 & 55.702 & 26.069 & S-6 & 11 & Zarasu, Litva & Zarasu, Litva \\
\hline 225 & $\mathrm{~N} / \mathrm{A}$ & 4 & 55.702 & 26.069 & S-6 & 11 & Zarasu, Litva & Zarasu, Litva \\
\hline 226 & $\mathrm{~N} / \mathrm{A}$ & 4 & 55.702 & 26.069 & $S-6$ & 11 & Zarasu, Litva & Zarasu, Litva \\
\hline 227 & $\mathrm{~N} / \mathrm{A}$ & 3 & 55.002 & 23.838 & $\mathrm{~S}-4$ & 11 & Kauno, Litva & Kauno, Litva \\
\hline 228 & $\mathrm{~N} / \mathrm{A}$ & 7 & 59.354 & 27.058 & $S-7$ & 12 & Pussi, Estonia & Pussi, Estonia \\
\hline 229 & $\mathrm{~N} / \mathrm{A}$ & 3 & 59.354 & 27.058 & S-7 & 12 & Pussi, Estonia & Pussi, Estonia \\
\hline 230 & $\mathrm{~N} / \mathrm{A}$ & 4 & 58.333 & 26.665 & S-7 & 12 & Lemmatsi, Estonia & Lemmatsi, Estonia \\
\hline 231 & $\mathrm{~N} / \mathrm{A}$ & 4 & 58.271 & 26.532 & S-7 & 12 & Noo, Estonia & Noo, Estonia \\
\hline 232 & $\mathrm{~N} / \mathrm{A}$ & 5 & 58.419 & 22.551 & $S-7$ & 12 & Saaremaa, Estonia & Saaremaa, Estonia \\
\hline 233 & $\mathrm{~N} / \mathrm{A}$ & 4 & 59.498 & 26.537 & S-7 & 12 & Kunda, Estonia & Kunda, Estonia \\
\hline 234 & $\mathrm{~N} / \mathrm{A}$ & 3 & 59.246 & 24.711 & S-7 & 12 & Todva, Estonia & Todva, Estonia \\
\hline 235 & $\mathrm{~N} / \mathrm{A}$ & 3 & 58.425 & 24.733 & S-7 & 12 & Tori-paikuse, Estonia & Tori-paikuse, Estonia \\
\hline 236 & $\mathrm{~N} / \mathrm{A}$ & 4 & 59.166 & 27.651 & $\mathrm{~S}-10$ & 12 & Puhatu, Estonia & Puhatu, Estonia \\
\hline 237 & $\mathrm{~N} / \mathrm{A}$ & 5 & 58.073 & 24.726 & S-7 & 12 & Parnu & Parnu \\
\hline 238 & $\mathrm{~N} / \mathrm{A}$ & 4 & 58.373 & 26.717 & S-7 & 12 & Tartumaa & Tartumaa \\
\hline 239 & R-21348 & 7 & 51.285 & 13.848 & $\mathrm{~N} / \mathrm{A}$ & 7 & Bohra Sa & Bohra sa \\
\hline 240 & $\mathrm{R}-107271$ & 3 & 48.948 & 15.042 & $\mathrm{~N} / \mathrm{A}$ & 7 & Avstriya, Litsehau & Austria, Litsehau \\
\hline 241 & R-76336 & 2 & 52.741 & 23.969 & $\mathrm{~S}-4$ & 7 & Belovezhskaya Pushcha & Bialowieza Forest \\
\hline 242 & R-76337 & 4 & 52.741 & 23.969 & S-4 & 7 & Belovezhskaya Pushcha & Bialowieza Forest \\
\hline 243 & R-11729 & 5 & 51.242 & 6.792 & $\mathrm{~N} / \mathrm{A}$ & 7 & Vestfaliya & Westphalia \\
\hline 244 & $8758 / 12$ & 3 & 48.955 & 28.743 & $\mathrm{~S}-11$ & 8 & Vinnickaya oblast' & Vinnytsia region \\
\hline 245 & $20746 / 72$ & 6 & 51.767 & 25.515 & S-5 & 8 & Volynskaya oblast', Lyubeshovsk. rajon & Volyn region, Lyubeshovsk. area \\
\hline 246 & $17134 / 61$ & 7 & 51.226 & 24.038 & $\mathrm{~S}-3$ & 8 & Volynskaya oblast', Lyuboml'sk. rajon & Volyn region, Lyubomlsk. area \\
\hline 247 & 13950 & 6 & 51.499 & 23.951 & $\mathrm{~S}-3$ & 3 & Volynskaya oblast', okr. SHacka & Volyn region, env. Shatsk \\
\hline 248 & 13949 & 7 & 51.499 & 23.951 & $\mathrm{~S}-3$ & 3 & Volynskaya oblast', okr. SHacka & Volyn region, env. Shatsk \\
\hline 249 & 13951 & 5 & 51.499 & 23.951 & $\mathrm{~S}-3$ & 3 & Volynskaya oblast', okr. SHacka & Volyn region, env. Shatsk \\
\hline 250 & $26215 / 34$ & 5 & 51.671 & 24.529 & $\mathrm{~S}-3$ & 8 & Volynskaya oblast', Ratnovsk. rajon & Volyn region, Ratnovsk. area \\
\hline
\end{tabular}




\begin{tabular}{|c|c|c|c|c|c|c|c|c|}
\hline 251 & $27133 / 41$ & 5 & 47.661 & 33.692 & $\mathrm{~S}-15$ & 8 & Dnepropetrovskaya oblast', Apostolovskij rajon & Dnipropetrovsk region, Apostolovsky district \\
\hline 252 & $27507 / 80$ & 5 & 47.661 & 33.692 & S-15 & 8 & Dnepropetrovskaya oblast', Apostolovskij rajon & Dnipropetrovsk region, Apostolovsky district \\
\hline 253 & $17011 / 58$ & 6 & 47.598 & 37.495 & $\mathrm{~S}-18$ & 8 & Doneckaya oblast', Volnovahskij rajon & Donetsk region, Volnovakha district \\
\hline 254 & $17012 / 59$ & 5 & 47.598 & 37.495 & S-18 & 8 & Doneckaya oblast', Volnovahskij rajon & Donetsk region, Volnovakha district \\
\hline 255 & $14630 / 50$ & 7 & 50.253 & 28.662 & $\mathrm{~S}-8$ & 8 & ZHitomir & Zhytomyr \\
\hline 256 & $26481 / 79$ & 4 & 50.101 & 29.634 & S-8 & 8 & ZHitomirskaya oblast', Popel'nyanskij rajon & Zhytomyr region, Popelnyan district \\
\hline 257 & $26480 / 78$ & 3 & 50.101 & 29.634 & $\mathrm{~S}-8$ & 8 & ZHitomirskaya oblast', Popel'nyanskij rajon & Zhytomyr region, Popelnyan district \\
\hline 258 & $21252 / 75$ & 4 & 50.461 & 28.674 & $\mathrm{~S}-8$ & 8 & ZHitomirskaya oblast', CHernyahovskij rajon & Zhytomyr region, Chernyakhovsky district \\
\hline 259 & $16493 / 57$ & 7 & 48.212 & 22.636 & $\mathrm{~N} / \mathrm{A}$ & 8 & Zakarpatskaya oblast', Beregovskij rajon & Transcarpathian region, Beregovo district \\
\hline 260 & $16492 / 56$ & 7 & 48.212 & 22.636 & $\mathrm{~N} / \mathrm{A}$ & 8 & Zakarpatskaya oblast', Beregovskij rajon & Transcarpathian region, Beregovo district \\
\hline 261 & $16490 / 54$ & 7 & 48.212 & 22.636 & $\mathrm{~N} / \mathrm{A}$ & 8 & Zakarpatskaya oblast', Beregovskij rajon & Transcarpathian region, Beregovo district \\
\hline 262 & $35463 / 99$ & 4 & 46.692 & 35.153 & $\mathrm{~L}-1$ & 8 & Zaporozhskaya oblast', Akimovskij rajon & Zaporozhye region, Akimov district \\
\hline 263 & $19884 / 68$ & 5 & 46.722 & 35.628 & $\mathrm{~L}-1$ & 8 & Zaporozhskaya oblast', Priazovskij rajon & Zaporizhia region, Priazovsky district \\
\hline 264 & 7551 & 4 & 45.961 & 29.483 & $\mathrm{~L}-1$ & 4 & |zmail'skaya oblast'ast' & Izmail region \\
\hline 265 & 7546 & 5 & 50.436 & 30.521 & $\mathrm{~S}-12$ & 4 & Kiev & Kiev \\
\hline 266 & $8759 / 13$ & 3 & 50.436 & 30.521 & $\mathrm{~S}-12$ & 8 & Kiev & Kiev \\
\hline 267 & $8753 / 7$ & 6 & 50.436 & 30.521 & $\mathrm{~S}-12$ & 8 & Kiev & Kiev \\
\hline 268 & $8754 / 8$ & 6 & 50.436 & 30.521 & $\mathrm{~S}-12$ & 8 & Kiev & Kiev \\
\hline 269 & $8764 / 18$ & 4 & 50.436 & 30.521 & S-12 & 8 & Kiev & Kiev \\
\hline 270 & $8763 / 17$ & 5 & 50.436 & 30.521 & $\mathrm{~S}-12$ & 8 & Kiev & Kiev \\
\hline 271 & $8757 / 11$ & 5 & 50.436 & 30.521 & $\mathrm{~S}-12$ & 8 & Kiev & Kiev \\
\hline 272 & $41195 / 105$ & 5 & 50.226 & 30.904 & $\mathrm{~S}-12$ & 8 & Kievskaya oblast', Borispol'skij rajon, Voronkov & Kiev region, Boryspil district, Voronkov \\
\hline 273 & $20659 / 98$ & 4 & 51.367 & 29.448 & S-8 & 8 & Kievskaya oblast', Polesskij rajon, Vil'cha & Kiev region, Polessky district, Vilcha \\
\hline 274 & $20662 / 70$ & 4 & 51.367 & 29.448 & $\mathrm{~S}-8$ & 8 & Kievskaya oblast', Polesskij rajon, Vil'cha & Kiev region, Polessky district, Vilcha \\
\hline 275 & $20660 / 86$ & 5 & 51.367 & 29.448 & $\mathrm{~S}-8$ & 8 & Kievskaya oblast', Polesskij rajon, Vil'cha & Kiev region, Polessky district, Vilcha \\
\hline 276 & $8784 / 38$ & 6 & 51.367 & 29.448 & $\mathrm{~S}-8$ & 8 & Kievskaya oblast', Polesskij rajon, Vil'cha & Kiev region, Polessky district, Vilcha \\
\hline 277 & $8778 / 32$ & 7 & 53.225 & 50.173 & $\mathrm{~S}-27$ & 8 & Kujbyshevskaya oblast' & Kuybyshev region \\
\hline 278 & $\mathrm{R}-60255$ & 7 & 52.121 & 35.095 & S-19 & 7 & Kurskaya oblast', Dmitriev-L'govskij & Kursk region, Dmitriev-Lgovsky \\
\hline 279 & R-60257 & 6 & 52.121 & 35.095 & S-19 & 7 & Kurskaya oblast', Dmitriev-L'govskij & Kursk region, Dmitriev-Lgovsky \\
\hline 280 & R-44094 & 6 & 52.121 & 35.095 & S-19 & 7 & Kurskaya oblast', Dmitriev-L'govskij & Kursk region, Dmitriev-Lgovsky \\
\hline 281 & $\mathrm{R}-60254$ & 2 & 52.121 & 35.095 & $\mathrm{~S}-19$ & 7 & Kurskaya oblast', Dmitriev-L'govskij & Kursk region, Dmitriev-Lgovsky \\
\hline 282 & $R-60253$ & 3 & 52.121 & 35.095 & S-19 & 7 & Kurskaya oblast', Dmitriev-L'govskij & Kursk region, Dmitriev-Lgovsky \\
\hline 283 & R-44098 & 5 & 52.121 & 35.095 & S-19 & 7 & Kurskaya oblast', Dmitriev-L'govskij & Kursk region, Dmitriev-Lgovsky \\
\hline 284 & R-44097 & 3 & 52.121 & 35.095 & S-19 & 7 & Kurskaya oblast', Dmitriev-L'govskij & Kursk region, Dmitriev-Lgovsky \\
\hline 285 & $\mathrm{R}-60251$ & 7 & 52.121 & 35.095 & $\mathrm{~S}-19$ & 7 & Kurskaya oblast', Dmitriev-L'govskij & Kursk region, Dmitriev-Lgovsky \\
\hline 286 & 7547 & 5 & 50.436 & 30.521 & $\mathrm{~S}-12$ & 4 & okrestnosti Kieva, ZHukov ostrov & outskirts of Kiev, Zhukov island \\
\hline 287 & 7548 & 4 & 50.436 & 30.521 & $\mathrm{~S}-12$ & 4 & okrestnosti Kieva, Irnen' & surroundings of Kiev, Irnen \\
\hline 288 & 7555 & 5 & 50.436 & 30.521 & $\mathrm{~S}-12$ & 4 & okrestnosti Kieva, Pushcha-Vodica & outskirts of Kiev, Puscha-Voditsa \\
\hline 289 & 13138 & 4 & 49.592 & 34.549 & S-15 & 3 & Poltava & Poltava \\
\hline 290 & 13132 & 7 & 49.592 & 34.549 & S-15 & 3 & Poltava & Poltava \\
\hline 291 & 13131 & 4 & 49.592 & 34.549 & S-15 & 3 & Poltava & Poltava \\
\hline
\end{tabular}




\begin{tabular}{|c|c|c|c|c|c|c|c|c|}
\hline 292 & 13130 & 6 & 49.592 & 34.549 & S-15 & 3 & Poltava & Poltava \\
\hline 293 & 13129 & 5 & 49.592 & 34.549 & S-15 & 3 & Poltava & Poltava \\
\hline 294 & 13128 & 6 & 49.592 & 34.549 & S-15 & 3 & Poltava & Poltava \\
\hline 295 & 13126 & 4 & 49.592 & 34.549 & S-15 & 3 & Poltava & Poltava \\
\hline 296 & 13135 & 4 & 49.867 & 34.727 & S-15 & 3 & Poltavskij uezd, Get'manshchina & Poltava County, Hetman \\
\hline 297 & 13137 & 4 & 48.945 & 34.108 & S-15 & 3 & Poltavskij uezd, Kovan'chino, r. Vorskla & Poltava County, Kovankino, r. Vorskla \\
\hline 298 & 13139 & 7 & 48.945 & 34.108 & S-15 & 3 & Poltavskij uezd, Kovan'chino, r. Vorskla & Poltava County, Kovankino, r. Vorskla \\
\hline 299 & 13143 & 6 & 48.945 & 34.108 & S-15 & 3 & Poltavskij uezd, Kovan'chino, r. Vorskla & Poltava County, Kovankino, r. Vorskla \\
\hline 300 & 13141 & 4 & 49.751 & 35.196 & $\mathrm{~S}-18$ & 3 & Poltavskij uezd, reka Kolomak & Poltava County, Kolomak River \\
\hline 301 & 13142 & 5 & 49.759 & 33.89 & $\mathrm{~S}-15$ & 3 & Poltavskij uezd, reka CHornen'ka & Poltava County, Chornya River \\
\hline 302 & $17133 / 60$ & 4 & 51.701 & 25.765 & S-5 & 8 & $\begin{array}{l}\text { Rovenskaya oblast', Zarechnenskij rajon, } \\
\text { Ostrovsk }\end{array}$ & Rivne region, Zarechnensky district, Ostrovsk \\
\hline 303 & $8783 / 37$ & 7 & 50.883 & 26.451 & S-5 & 8 & Rovenskaya Oblast', Kostopol'skij rajon & Rivne Region, Kostopil Region \\
\hline 304 & $8775 / 29$ & 7 & 50.883 & 26.451 & S-5 & 8 & Rovenskaya Oblast', Kostopol'skij rajon & Rivne Region, Kostopil Region \\
\hline 305 & 21339 & 4 & 52.301 & 33.798 & S-16 & 3 & $\begin{array}{l}\text { Sumskaya oblast', Seredinogubskij rajon, } \\
\text { Staraya guba }\end{array}$ & Sumy region, Seredinogubsky district, Old Bay \\
\hline 306 & 21354 & 5 & 53.152 & 38.131 & $\mathrm{~S}-21$ & 3 & Tul'skaya oblast', Efremovskij rajon & Tula region, Efremovsky district \\
\hline 307 & R-75278 & 3 & 53.924 & 37.691 & $\mathrm{~S}-21$ & 7 & Tul'skaya oblast', Novosil'skij rajon & Tula region, Novosilsky district \\
\hline 308 & $R-116306$ & 3 & 54.351 & 38.263 & $\mathrm{~S}-21$ & 7 & Tul'skaya oblast', Venevskij rajon & Tula region, Venevsky district \\
\hline 309 & R-75279 & 7 & 53.924 & 37.691 & S-21 & 7 & Tul'skaya oblast'ast', Novosil'skij rajon & Tula region, Novosilsky district \\
\hline 310 & R-75276 & 6 & 53.924 & 37.691 & $\mathrm{~S}-21$ & 7 & Tul'skaya oblast'ast', Novosil'skij rajon & Tula region, Novosilsky district \\
\hline 311 & R-11753 & 5 & 54.192 & 46.974 & S-26 & 7 & Ul'yanovskaya oblast', Karsunskij rajon & Ulyanovsk region, Karsunsky district \\
\hline 312 & R-11755 & 2 & 54.192 & 46.974 & $\mathrm{~S}-26$ & 7 & Ul'yanovskaya oblast', Karsunskij rajon & Ulyanovsk region, Karsunsky district \\
\hline 313 & R-11763 & 3 & 54.192 & 46.974 & $\mathrm{~S}-26$ & 7 & Ul'yanovskaya oblast', Karsunskij rajon & Ulyanovsk region, Karsunsky district \\
\hline 314 & $\mathrm{R}-11762$ & 5 & 53.789 & 47.511 & S-26 & 7 & Ul'yanovskaya oblast', Pronzino & Ulyanovsk region, Pronzino \\
\hline 315 & $R-11756$ & 6 & 54.192 & 46.974 & S-26 & 7 & Ul'yanovskaya oblast', Karsunskij rajon & Ulyanovsk region, Karsunsky district \\
\hline 316 & $\mathrm{R}-11750$ & 3 & 54.192 & 46.974 & $\mathrm{~S}-26$ & 7 & Ul'yanovskaya oblast', Karsunskij rajon & Ulyanovsk region, Karsunsky district \\
\hline 317 & R-11759 & 6 & 54.192 & 46.974 & S-26 & 7 & Ul'yanovskaya oblast', Karsunskij rajon & Ulyanovsk region, Karsunsky district \\
\hline 318 & $\mathrm{R}-11760$ & 6 & 54.192 & 46.974 & $\mathrm{~S}-26$ & 7 & Ul'yanovskaya oblast', Karsunskij rajon & Ulyanovsk region, Karsunsky district \\
\hline 319 & 21348 & 6 & 49.992 & 36.206 & $\mathrm{~S}-18$ & 3 & Har'kov, Lozoven'ki & Kharkov, Lozovenki \\
\hline 320 & 21350 & 7 & 49.992 & 36.206 & $\mathrm{~S}-18$ & 3 & Har'kov, Pomerki & Kharkov, Pomerki \\
\hline 321 & 13145 & 6 & 49.638 & 36.636 & $\mathrm{~S}-18$ & 3 & Har'kovskaya oblast' & Kharkov region \\
\hline 322 & 13146 & 4 & 49.638 & 36.636 & S-18 & 3 & Har'kovskaya oblast'ast' & Kharkiv region \\
\hline 323 & 21352 & 5 & 49.702 & 36.352 & $\mathrm{~S}-18$ & 3 & $\begin{array}{l}\text { Har'kovskaya oblast', Zmievskij rajon, Severnyj } \\
\text { Donec }\end{array}$ & $\begin{array}{l}\text { Kharkiv region, Zmievsky district, Northern } \\
\text { Donets }\end{array}$ \\
\hline 324 & 21351 & 6 & 49.702 & 36.352 & $\mathrm{~S}-18$ & 3 & $\begin{array}{l}\text { Har'kovskaya oblast', Zmievskij rajon, Severnyj } \\
\text { Donec }\end{array}$ & $\begin{array}{l}\text { Kharkiv region, Zmievsky district, Northern } \\
\text { Donets }\end{array}$ \\
\hline 325 & 21349 & 4 & 49.992 & 36.206 & $\mathrm{~S}-18$ & 3 & Har'kov, Pomerki & Kharkov, Pomerki \\
\hline 326 & 19395/66 & 3 & 46.511 & 33.978 & $\mathrm{~L}-1$ & 8 & $\begin{array}{l}\text { Hersonskaya oblast', CHaplinskij rajon, Askaniya- } \\
\text { nova }\end{array}$ & $\begin{array}{l}\text { Kherson region, Chaplinsky district, Askania- } \\
\text { Nova }\end{array}$ \\
\hline 327 & $8770 / 24$ & 3 & 46.371 & 33.541 & $\mathrm{~L}-1$ & 8 & $\begin{array}{l}\text { Hersonskaya oblast', CHaplinskij rajon, } \\
\text { CHaplinka }\end{array}$ & Kherson region, Chaplinsky district, Chaplinka \\
\hline 328 & $19394 / 65$ & 3 & 46.511 & 33.978 & $\mathrm{~L}-1$ & 8 & $\begin{array}{l}\text { Hersonskaya oblast', CHaplinskij rajon, Askaniya- } \\
\text { nova }\end{array}$ & $\begin{array}{l}\text { Kherson region, Chaplinsky district, Askania- } \\
\text { Nova }\end{array}$ \\
\hline
\end{tabular}




\begin{tabular}{|c|c|c|c|c|c|c|c|c|}
\hline 329 & $37780 / 97$ & 5 & 51.135 & 30.964 & S-12 & 8 & $\begin{array}{l}\text { CHernigovskaya oblast', Kozeleckij rajon, } \\
\text { Samojlovka }\end{array}$ & Chernihiv region, Kozelets district, Samoilovka \\
\hline 330 & $8760 / 14$ & 4 & 51.042 & 31.888 & $\mathrm{~S}-12$ & 8 & CHernigovskaya oblast', Nezhinskij rajon, Nezhin & Chernihiv region, Nezhinsky district, Nezhin \\
\hline 331 & $8749 / 3$ & 2 & 51.812 & 31.091 & $\mathrm{~S}-12$ & 8 & CHernigovskaya oblast', Repkinskij rajon & Chernihiv region, Repkinsky district \\
\hline 332 & $8765 / 19$ & 5 & 51.812 & 31.091 & $\mathrm{~S}-12$ & 8 & CHernigovskaya oblast', Repkinskij rajon & Chernihiv region, Repkinsky district \\
\hline 333 & $8756 / 10$ & 5 & 51.812 & 31.091 & $\mathrm{~S}-12$ & 8 & CHernigovskaya oblast', Repkinskij rajon & Chernihiv region, Repkinsky district \\
\hline 334 & $8752 / 6$ & 3 & 51.812 & 31.091 & $\mathrm{~S}-12$ & 8 & CHernigovskaya oblast', Repkinskij rajon & Chernihiv region, Repkinsky district \\
\hline 335 & $8755 / 9$ & 3 & 51.812 & 31.091 & $\mathrm{~S}-12$ & 8 & CHernigovskaya oblast', Repkinskij rajon & Chernihiv region, Repkinsky district \\
\hline 336 & $8762 / 16$ & 4 & 51.812 & 31.091 & $\mathrm{~S}-12$ & 8 & CHernigovskaya oblast', Repkinskij rajon & Chernihiv region, Repkinsky district \\
\hline 337 & $8748 / 2$ & 5 & 51.812 & 31.091 & $\mathrm{~S}-12$ & 8 & CHernigovskaya oblast', Repkinskij rajon & Chernihiv region, Repkinsky district \\
\hline 338 & $8751 / 5$ & 5 & 51.918 & 30.965 & $\mathrm{~S}-12$ & 8 & CHernigovskaya oblast', Repkinskij rajon, Vir & Chernihiv region, Repkinsky district, Vir \\
\hline 339 & $8781 / 35$ & 7 & 51.918 & 30.965 & $\mathrm{~S}-12$ & 8 & CHernigovskaya oblast', Repkinskij rajon, Vir & Chernihiv region, Repkinsky district, Vir \\
\hline 340 & $8772 / 26$ & 7 & 51.967 & 30.931 & $\mathrm{~S}-12$ & 8 & CHernigovskaya oblast', Repkinskij rajon, Vir & Chernihiv region, Repkinsky district, Vir \\
\hline 341 & $8773 / 27$ & 6 & 51.967 & 30.931 & $\mathrm{~S}-12$ & 8 & CHernigovskaya oblast', Repkinskij rajon, Vir & Chernihiv region, Repkinsky district, Vir \\
\hline 342 & $8747 / 1$ & 4 & 51.967 & 30.931 & $\mathrm{~S}-12$ & 8 & CHernigovskaya oblast', Repkinskij rajon, Vir & Chernihiv region, Repkinsky district, Vir \\
\hline 343 & $8792 / 46$ & 5 & 51.967 & 30.931 & $\mathrm{~S}-12$ & 8 & CHernigovskaya oblast', Repkinskij rajon, Vir & Chernihiv region, Repkinsky district, Vir \\
\hline 344 & 8767/21 & 6 & 51.967 & 30.931 & S-12 & 8 & $\begin{array}{l}\text { CHernigovskaya oblast', Repkinskij rajon, } \\
\text { Klubovka }\end{array}$ & Chernihiv region, Repkinsky district, Klubovka \\
\hline 345 & $8766 / 20$ & 4 & 51.951 & 30.949 & S-12 & 8 & $\begin{array}{l}\text { CHernigovskaya oblast', Repkinskij rajon, } \\
\text { Brekhunovka }\end{array}$ & Chernihiv region, Repkinsky district, Brehunovka \\
\hline 346 & $8750 / 4$ & 5 & 51.918 & 30.965 & $\mathrm{~S}-12$ & 8 & CHernigovskaya oblast', Repkinskij rajon, Vir & Chernihiv region, Repkinsky district, Vir \\
\hline 347 & $8793 / 47$ & 5 & 51.918 & 30.965 & $\mathrm{~S}-12$ & 8 & CHernigovskaya oblast', Repkinskij rajon, Vir & Chernihiv region, Repkinsky district, Vir \\
\hline 348 & $21171 / 74$ & 4 & 51.903 & 31.857 & $\mathrm{~S}-12$ & 8 & $\begin{array}{l}\text { CHernigovskaya oblast', SHCHorskij rajon, } \\
\text { Borovichi }\end{array}$ & Chernihiv region, Shchorsky district, Borovichi \\
\hline 349 & $\mathrm{R}-60265$ & 7 & 54.911 & 32.875 & $\mathrm{~S}-16$ & 7 & Smolensk. oblast' & Smolensk. region \\
\hline 350 & R-60266 & 7 & 54.911 & 32.875 & S-16 & 7 & Smolensk. oblast' & Smolensk. region \\
\hline 351 & $\mathrm{R}-60264$ & 7 & 54.911 & 32.875 & S-16 & 7 & Smolensk. oblast' & Smolensk. region \\
\hline 352 & $\mathrm{R}-60267$ & 4 & 54.911 & 32.875 & $\mathrm{~S}-16$ & 7 & Smolensk. oblast' & Smolensk. region \\
\hline 353 & $\mathrm{R}-60268$ & 6 & 55.215 & 34.301 & $\mathrm{~S}-17$ & 7 & Smolenskaya oblast', Vyazemskij rajon & Smolensk region, Vyazemsky district \\
\hline 354 & 21344 & 3 & 55.066 & 32.686 & S-17 & 3 & Smolenskaya oblast', YArcevskij uezd & Smolensk region, Yartsevo district \\
\hline 355 & $\mathrm{~N} / \mathrm{A}$ & 4 & 52.715 & 25.349 & $\mathrm{~S}-4$ & 6 & Belorussiya, Ivacevichsk. rajon & Belarus, Ivatsevichsky. area \\
\hline 356 & N/A & 5 & 52.051 & 27.932 & S-8 & 6 & $\begin{array}{l}\text { Belorussiya, Gomel'sk. ZHitkovichsk. rajon. } \\
\text { Hvoensk }\end{array}$ & Belarus, Gomel. Zhitkovichsk. area. Hvoensk \\
\hline 357 & $1459 / 109$ & 6 & 53.139 & 29.227 & $\mathrm{~S}-9$ & 6 & Belorussiya, Bobrujsk & Belarus, Bobruisk \\
\hline 358 & $1474 \backslash 1645$ & 4 & 54.783 & 33.413 & S-16 & 6 & $\begin{array}{l}\text { Smolenskaya oblast', Dorogobuzhskij rajon, } \\
\text { Aleksino }\end{array}$ & Smolensk region, Dorogobuzh district, Aleksino \\
\hline 359 & $1460 \backslash 2990$ & 3 & 54.783 & 33.413 & S-16 & 6 & $\begin{array}{l}\text { Smolenskaya oblast', Dorogobuzhskij rajon, } \\
\text { Aleksino }\end{array}$ & Smolensk region, Dorogobuzh district, Aleksino \\
\hline 360 & N/A & 4 & 51.782 & 23.639 & S-3 & 6 & $\begin{array}{l}\text { Brestskaya oblast'ast', Leninskij rajon, } \\
\text { Dubeckaya }\end{array}$ & Brest region, Leninsky district, Dubetskaya \\
\hline 361 & N/A & 3 & 51.832 & 26.999 & S-5 & 6 & Brestskaya oblast', Stolinskij rajon, Koshara-ol'm & Brest region, Stolin district, Koshara-olm \\
\hline 362 & N/A & 4 & 52.741 & 23.969 & $\mathrm{~S}-4$ & 6 & Belovezhskaya Pushcha & Bialowieza Forest \\
\hline
\end{tabular}




\begin{tabular}{|c|c|c|c|c|c|c|c|c|}
\hline 363 & N/A & 7 & 51.782 & 23.639 & $\mathrm{~S}-3$ & 6 & $\begin{array}{l}\text { Brestskaya oblast'ast', Leninskij rajon, } \\
\text { Dubeckaya }\end{array}$ & Brest region, Leninsky district, Dubetskaya \\
\hline 364 & 1388 & 6 & 52.443 & 30.978 & $\mathrm{~S}-12$ & 6 & Gomel' & Gomel \\
\hline 365 & 1392 & 4 & 52.065 & 28.383 & $\mathrm{~S}-8$ & 6 & Mozyrskij rajon, Mordvin & Mozyr District, Mordvin \\
\hline 366 & 1397 & 7 & 51.832 & 26.999 & S-5 & 6 & Brestskaya oblast', Stolinskij rajon, Koshara-ol'm & Brest region, Stolin district, Koshara-olm \\
\hline 367 & 1387 & 6 & 51.832 & 26.999 & $S-5$ & 6 & Gomel'skaya oblast' & Gomel region \\
\hline 368 & 1378 & 5 & 52.443 & 30.978 & $\mathrm{~S}-12$ & 6 & Gomel' & Gomel \\
\hline 369 & 1394 & 7 & 52.443 & 30.978 & $\mathrm{~S}-12$ & 6 & Gomel' & Gomel \\
\hline 370 & 1384 & 4 & 52.443 & 30.978 & $\mathrm{~S}-12$ & 6 & Gomel' & Gomel \\
\hline 371 & 1383 & 5 & 52.443 & 30.978 & $\mathrm{~S}-12$ & 6 & Gomel' & Gomel \\
\hline 372 & 1386 & 5 & 52.443 & 30.978 & $\mathrm{~S}-12$ & 6 & Gomel' & Gomel \\
\hline 373 & 1377 & 5 & 52.443 & 30.978 & $\mathrm{~S}-12$ & 6 & Gomel' & Gomel \\
\hline 374 & 2306 & 4 & 52.033 & 27.848 & S-8 & 6 & Gomel'skaya oblast', ZHitkovich rajon, Ozerany & Gomel region, Zhitkovich district, Ozeryan \\
\hline 375 & $\mathrm{~N} / \mathrm{A}$ & 7 & 49.837 & 24.034 & $\mathrm{~S}-3$ & 5 & L'Vov & Lviv \\
\hline 376 & $\mathrm{~N} / \mathrm{A}$ & 7 & 50.101 & 25.732 & S-5 & 5 & Ternopol', Kremenec & Ternopil, Kremenets \\
\hline 377 & $\mathrm{~N} / \mathrm{A}$ & 7 & 52.626 & 20.385 & S-1 & 9 & Pol'sha, Plon'sk & Poland, Plonsk \\
\hline 378 & $\mathrm{~N} / \mathrm{A}$ & 6 & 50.597 & 27.607 & S-8 & 9 & ZHitomirskaya oblast', Novograd & Zhytomyr region, Novograd \\
\hline 379 & $\mathrm{~N} / \mathrm{A}$ & 5 & 50.436 & 30.521 & $\mathrm{~S}-12$ & 9 & Kiev & Kiev \\
\hline 380 & $\mathrm{~N} / \mathrm{A}$ & 6 & 52.626 & 20.385 & S-1 & 9 & Pol'sha, Plon'sk & Poland, Plonsk \\
\hline 381 & N/A & 4 & 49.267 & 30.932 & S-11 & 9 & $\begin{array}{l}\text { CHerkasska oblast', Lysnyanskij rajon, } \\
\text { Pochapicy }\end{array}$ & $\begin{array}{l}\text { Cherkassk region, Lysnyansky district, } \\
\text { Pochapitsy }\end{array}$ \\
\hline 382 & N/A & 7 & 49.267 & 30.932 & $\mathrm{~S}-11$ & 9 & $\begin{array}{l}\text { CHerkasska oblast', Lysnyanskij rajon, } \\
\text { Pochapicy }\end{array}$ & $\begin{array}{l}\text { Cherkassk region, Lysnyansky district, } \\
\text { Pochapitsy }\end{array}$ \\
\hline 383 & $\mathrm{~N} / \mathrm{A}$ & 5 & 52.231 & 20.996 & S-1 & 9 & Varshava & Warsaw \\
\hline 384 & $\mathrm{~N} / \mathrm{A}$ & 6 & 52.231 & 20.996 & S-1 & 9 & Varshava & Warsaw \\
\hline 385 & N/A & 5 & 49.267 & 30.932 & S-11 & 9 & $\begin{array}{l}\text { CHerkasska oblast', Lysnyanskij rajon, } \\
\text { Pochapicy }\end{array}$ & $\begin{array}{l}\text { Cherkassk region, Lysnyansky district, } \\
\text { Pochapitsy }\end{array}$ \\
\hline 386 & $\mathrm{~N} / \mathrm{A}$ & 7 & 52.626 & 20.385 & S-1 & 9 & Pol'sha, Plon'sk & Poland, Plonsk \\
\hline 387 & N/A & 5 & 49.267 & 30.932 & S-11 & 9 & $\begin{array}{l}\text { CHerkasska oblast', Lysnyanskij rajon, } \\
\text { Pochapicy }\end{array}$ & $\begin{array}{l}\text { Cherkassk region, Lysnyansky district, } \\
\text { Pochapitsy }\end{array}$ \\
\hline 388 & N/A & 4 & 49.267 & 30.932 & S-11 & 9 & $\begin{array}{l}\text { CHerkasska oblast', Lysnyanskij rajon, } \\
\text { Pochapicy }\end{array}$ & $\begin{array}{l}\text { Cherkassk region, Lysnyansky district, } \\
\text { Pochapitsy }\end{array}$ \\
\hline 389 & $\mathrm{~N} / \mathrm{A}$ & 7 & 46.694 & 31.236 & $\mathrm{~L}-1$ & 9 & Odesskaya oblast', Koblast'evo & Odessa region, Koblastievo \\
\hline 390 & $\mathrm{~N} / \mathrm{A}$ & 7 & 52.231 & 20.996 & S-1 & 9 & Varshava & Warsaw \\
\hline 391 & $\mathrm{~N} / \mathrm{A}$ & 7 & 52.231 & 20.996 & S-1 & 9 & Varshava & Warsaw \\
\hline 392 & $\mathrm{~N} / \mathrm{A}$ & 4 & 52.184 & 25.849 & S-5 & 9 & Pinsk, vyzhlovichi & Pinsk, Vyzhlovichi \\
\hline 393 & $\mathrm{~N} / \mathrm{A}$ & 4 & 52.231 & 20.996 & S-1 & 9 & Varshava & Warsaw \\
\hline 394 & $\mathrm{~N} / \mathrm{A}$ & 4 & 52.231 & 20.996 & S-1 & 9 & Varshava & Warsaw \\
\hline 395 & $\mathrm{~N} / \mathrm{A}$ & 5 & 52.231 & 20.996 & S-1 & 9 & Varshava & Warsaw \\
\hline 396 & $\mathrm{~N} / \mathrm{A}$ & 5 & 50.049 & 29.633 & S-8 & 9 & $\begin{array}{l}\text { ZHitomirirskaya oblast', Popel'nyanskij rajon, } \\
\text { Mohnachka }\end{array}$ & $\begin{array}{l}\text { Zhytomyr region, Popelnyan district, } \\
\text { Mokhnachka }\end{array}$ \\
\hline 397 & $\mathrm{~N} / \mathrm{A}$ & 4 & 52.231 & 20.996 & S-1 & 9 & Varshava & Warsaw \\
\hline
\end{tabular}




\begin{tabular}{|c|c|c|c|c|c|c|c|c|}
\hline 398 & $\mathrm{~N} / \mathrm{A}$ & 6 & 52.184 & 25.849 & S-5 & 9 & Pinsk, vyzhlovichi & Pinsk, Vyzhlovichi \\
\hline 399 & $\mathrm{~N} / \mathrm{A}$ & 4 & 52.231 & 20.996 & S-1 & 9 & Varshava & Warsaw \\
\hline 400 & $\mathrm{~N} / \mathrm{A}$ & 7 & 52.231 & 20.996 & S-1 & 9 & Varshava & Warsaw \\
\hline 401 & $\mathrm{~N} / \mathrm{A}$ & 6 & 50.279 & 36.943 & S-19 & 9 & Har'kovskaya oblast'ast', Volchanskij rajon & Kharkiv region, Volchansky district \\
\hline 402 & N/A & 4 & 49.267 & 30.932 & S-11 & 9 & $\begin{array}{l}\text { CHerkasska oblast', Lysnyanskij rajon, } \\
\text { Pochapicy }\end{array}$ & $\begin{array}{l}\text { Cherkassk region, Lysnyansky district, } \\
\text { Pochapitsy }\end{array}$ \\
\hline 403 & N/A & 5 & 49.267 & 30.932 & $\mathrm{~S}-11$ & 9 & $\begin{array}{l}\text { CHerkasska oblast', Lysnyanskij rajon, } \\
\text { Pochapicy }\end{array}$ & $\begin{array}{l}\text { Cherkassk region, Lysnyansky district, } \\
\text { Pochapitsy }\end{array}$ \\
\hline 404 & $\mathrm{~N} / \mathrm{A}$ & 6 & 49.267 & 30.932 & S-11 & 9 & $\begin{array}{l}\text { CHerkasska oblast', Lysnyanskij rajon, } \\
\text { Pochapicy }\end{array}$ & $\begin{array}{l}\text { Cherkassk region, Lysnyansky district, } \\
\text { Pochapitsy }\end{array}$ \\
\hline 405 & $\mathrm{~N} / \mathrm{A}$ & 6 & 52.231 & 20.996 & $\mathrm{~S}-1$ & 9 & Varshava & Warsaw \\
\hline 406 & $\mathrm{~N} / \mathrm{A}$ & 7 & 52.231 & 20.996 & S-1 & 9 & Varshava & Warsaw \\
\hline 407 & $\mathrm{~N} / \mathrm{A}$ & 5 & 50.346 & 22.236 & S-1 & 9 & Galiciya & Galicia \\
\hline 408 & $\mathrm{~N} / \mathrm{A}$ & 4 & 52.231 & 20.996 & S-1 & 9 & Varshava & Warsaw \\
\hline 409 & $\mathrm{~N} / \mathrm{A}$ & 7 & 50.148 & 26.182 & S-5 & 9 & Ternopol'sk oblast', Kremenskij rajon, Surazh & Ternopil region, Kremensky district, Surazh \\
\hline 410 & $\mathrm{~N} / \mathrm{A}$ & 3 & 54.911 & 32.875 & S-16 & 9 & Smolenskaya oblast' & Smolensk region \\
\hline 411 & N/A & 4 & 52.601 & 36.349 & S-19 & 9 & Orlovskaya oblast', Karachaevskij rajon & Oryol region, Karachay district \\
\hline 412 & $\mathrm{~N} / \mathrm{A}$ & 5 & 51.097 & 40.041 & $\mathrm{~L}-2$ & 9 & Voronezhskaya oblast'ast', Bobrovskij rajon & Voronezh region, Bobrovsky district \\
\hline 413 & $\mathrm{~N} / \mathrm{A}$ & 4 & 55.788 & 49.173 & $\mathrm{~S}-28$ & 9 & Kazan' & Kazan \\
\hline 414 & $\mathrm{~N} / \mathrm{A}$ & 5 & 53.934 & 39.101 & $\mathrm{~S}-21$ & 9 & $\begin{array}{l}\text { Ryazanskaya oblast'ast', Mihajlovskij rajon, } \\
\text { Nyuhovec }\end{array}$ & Ryazan region, Mikhailovsky district, Nyukhovets \\
\hline 415 & $\mathrm{~N} / \mathrm{A}$ & 4 & 53.924 & 37.691 & $\mathrm{~S}-21$ & 9 & Tul'skaya oblast'ast', Novosil'skij rajon. & Tula region, Novosilsky district. \\
\hline 416 & $\mathrm{~N} / \mathrm{A}$ & 4 & 53.152 & 38.131 & $\mathrm{~S}-21$ & 9 & Tul'skaya oblast', Efremovskij rajon & Tula region, Efremovsky district \\
\hline 417 & N/A & 6 & 51.097 & 40.041 & $\mathrm{~L}-2$ & 9 & Voronezhskaya oblast'ast', Bobrovskij rajon & Voronezh region, Bobrovsky district \\
\hline 418 & $\mathrm{~N} / \mathrm{A}$ & 6 & 53.934 & 38.801 & $\mathrm{~S}-21$ & 9 & Granica Tula-Ryazan' & Border Tula-Ryazan \\
\hline 419 & N/A & 7 & 53.934 & 38.801 & S-21 & 9 & Granica Tula-Ryazan' & Border Tula-Ryazan \\
\hline 420 & $\mathrm{~N} / \mathrm{A}$ & 7 & 51.097 & 40.041 & $\mathrm{~L}-2$ & 9 & Voronezhskaya oblast'ast', Bobrovskij rajon & Voronezh region, Bobrovsky district \\
\hline 421 & $\mathrm{R}-3840$ & 6 & 45.20 & 34.29 & $\mathrm{~N} / \mathrm{A}$ & 7 & Krym & Crimea \\
\hline 422 & $\mathrm{R}-6128$ & 4 & 55.31 & 35.42 & $\mathrm{~S}-20$ & 7 & Moskovskaya oblast', Mozhajskij rajon & Moscow region, Mozhaisky district \\
\hline 423 & R-11728 & 6 & 57.32 & 26.57 & S-6 & 7 & Liflyandiya, Marienburg, Volkskij uezd & Livonia, Marienburg, Volk County \\
\hline 424 & R-11761 & 7 & 53.39 & 48.30 & $\mathrm{~S}-26$ & 7 & Ul'yanovskaya oblast', Gremyachij klyuch & Ulyanovsk region, Gremyachy key \\
\hline 425 & $R-11767$ & 6 & 56.53 & 74.22 & N/A & 7 & Tobol'skaya oblast', v 12 verstah ot goroda Tara & Tobolsk region, 12 versts from the city of Tara \\
\hline 426 & R-15995 & 6 & 52.00 & 56.55 & S-29 & 7 & YUzhnyj Ural, Ziyangurinskij & South Ural, Zyangurinsky \\
\hline 427 & R-24065 & 4 & 44.35 & 40.06 & $\mathrm{~N} / \mathrm{A}$ & 7 & Majkop & Maykop \\
\hline 428 & R-60210 & 7 & 55.41 & 38.13 & $\mathrm{~S}-22$ & 7 & Moskovskaya oblast', Noginskij rajon & Moscow region, Noginsk district \\
\hline 429 & R-60228 & 6 & 55.41 & 38.13 & $\mathrm{~S}-22$ & 7 & Moskovskaya oblast', Noginskij rajon & Moscow region, Noginsk district \\
\hline 430 & R-60258 & 6 & 56.45 & 38.41 & $\mathrm{~S}-22$ & 7 & YAroslavskaya oblast', Ozero Pleshchevo & Yaroslavl region, Lake Pleschevo \\
\hline 431 & R-75277 & 7 & 53.16 & 37.11 & $\mathrm{~S}-21$ & 7 & Tul'skayaoblast', Novosil'skij rajon & Tula region, Novosilsky district \\
\hline 432 & $\mathrm{R}-102886$ & 3 & 42.24 & 47.45 & $\mathrm{~N} / \mathrm{A}$ & 7 & Dagestan, Izberbashskij rajon, selo Utamysh & Dagestan, Izberbash district, village Utamysh \\
\hline
\end{tabular}




\section{Colour type \\ Latitude.S-N \\ Longitude.W-E \\ Location (transliterated) \\ Location (translated)}

\section{Population ID}

\section{Museum}

Drost's colour score value

Latitude

Longitude

Place of bird detection indicated on tag (transliterated)

Place of bird detection indicated on tag (machine translation)

Population IDs formed by the bird skins; labled as L-1, L-2, etc. for large populations and S-1, S-2, etc. for small populations, respectively (please also see Fig. S4 and Table S2). N/A - skins of birds not included in any population.

Museum identifier:

[2] Collection of the Department of Biogeography of the Faculty of Geography of the M. V. Lomonosov Moscow State University (Moscow)

[3] State Museum of Nature of the Kharkiv National V.N. Karazin University (Kharkiv)

[4] Zoological Museum of Kyiv National Taras Shevchenko University (Kiev)

[5] Zoological Museum of Lviv National I. Frank University (Lviv)

[6] Zoological Museum of the Belarusian State University (Minsk)

[7] Zoological Museum of the M. V. Lomonosov Moscow State University (Moscow)

[8] Zoological Museum of the National Academy of Sciences of Ukraine (Kiev)

[9] Zoological Museum of the Zoological Institute of the Russian Academy of Sciences (St. Petersburg)

[10] Kirov City Zoological Museum (Kirov)

[11] Kaunas Zoological T. Ivanauskas Museum (Kaunas)

[12] Museum of Natural History of Tartu University (Tartu) 